\title{
Can phosphorus application and cover cropping alter arbuscular mycorrhizal fungal communities and soybean performance after a 5-year phosphorus-unfertilized crop rotational system?
}

\author{
Masao Higo ${ }^{\text {Corresp.. }}{ }^{1}$, Ryohei Sato ${ }^{1}$, Ayu Serizawa ${ }^{1}$, Yuichi Takahashi ${ }^{1}$, Kento Gunji $^{1}$, Yuya Tatewaki ${ }^{1}$, \\ Katsunori Isobe ${ }^{1}$ \\ ${ }^{1}$ Department of Agricultural Bioscience, College of Bioresource Sciences, Nihon University, Kanagawa, Japan \\ Corresponding Author: Masao Higo \\ Email address: higo.masao@nihon-u.ac.jp
}

Background: Understanding diversity of arbuscular mycorrhizal fungi (AMF) is important for optimizing their role for phosphorus (P) nutrition of soybeans (Glycine max (L.) Merr.) in P-limited soils. However, it is not clear how soybean growth and $P$ nutrition is related to AMF colonization and diversity of AMF communities in a continuous P-unfertilized cover cropping system. Thus, we investigated the impact of Papplication and cover cropping on the interaction among AMF colonization, AMF diversity in soybean roots, soybean growth and $\mathrm{P}$ nutrition under a 5-year P-unfertilized crop rotation.

Methods: In this study, we established three cover crop systems (wheat, red clover, and oilseed rape) or bare fallow in rotation with soybean. The P-application rates before the seeding of soybeans were 52.5 and $157.5 \mathrm{~kg} \mathrm{ha}^{-1}$ in 2014 and 2015, respectively. We measured AMF colonization in soybean roots, soybean growth parameters such as aboveground plant biomass, $\mathrm{P}$ uptake at the flowering stage and grain yields at the maturity stage in both years. AMF community structure in soybean roots was characterized by specific amplification of small subunit (SSU) rDNA.

Results: The increase in the root colonization at the flowering stage was small as a result of Papplication. Cover cropping did not affect the aboveground biomass and $P$ uptake of soybean in both years, but the P-application had positive effects on the soybean performance such as plant $\mathrm{P}$ uptake, biomass and grain yield in 2015. AMF communities colonizing soybean roots were also significantly influenced by P-application throughout the two years. Moreover, the diversity of AMF communities in roots was significantly influenced by P-application and cover cropping in both years, and was positively correlated with the soybean biomass, $\mathrm{P}$ uptake and grain yield throughout the two years.

Discussion: Our results indicated that P-application rather than cover cropping may be a key factor for improving soybean growth performance with respect to AMF diversity in P-limited cover cropping systems. Additionally, AMF diversity in roots can potentially contribute to soybean $\mathrm{P}$ nutrition even in the P-fertilized cover crop rotational system. Therefore, further investigation into the interaction of AMF diversity, P-application and cover cropping is required for the development of more effective $P$ management practices on soybean growth performance. 
1 Title: Can phosphorus application and cover cropping alter arbuscular mycorrhizal fungal

2 communities and soybean performance after a 5-year phosphorus-unfertilized crop rotational

$3 \quad$ system?

5 Masao Higo $^{1 *}$, Ryohei Sato ${ }^{1}$, Ayu Serizawa ${ }^{1}$, Yuichi Takahashi ${ }^{1}$, Kento Gunji ${ }^{1}$, Yuya Tatewaki ${ }^{1}$, 6 Katsunori Isobe ${ }^{1}$

8 1) Department of Agricultural Bioscience, College of Bioresource Sciences, Nihon University,

9 Fujisawa, Kanagawa 252-0880, Japan

10 Tel: +81-466-84-3502; Fax: +81-466-84-3525

$11 *$ Corresponding author

12 E-mail: higo.masao@nihon-u.ac.jp

\section{Abstract}

Background: Understanding diversity of arbuscular mycorrhizal fungi (AMF) is important for optimizing their role for phosphorus (P) nutrition of soybeans (Glycine max (L.) Merr.) in Plimited soils. However, it is not clear how soybean growth and P nutrition is related to AMF colonization and diversity of AMF communities in a continuous P-unfertilized cover cropping system. Thus, we investigated the impact of P-application and cover cropping on the interaction among AMF colonization, AMF diversity in soybean roots, soybean growth and $\mathrm{P}$ nutrition under a 5-year P-unfertilized crop rotation.

Methods: In this study, we established three cover crop systems (wheat, red clover, and oilseed rape) or bare fallow in rotation with soybean. The $\mathrm{P}$-application rates before the seeding of soybeans were 52.5 and $157.5 \mathrm{~kg} \mathrm{ha}^{-1}$ in 2014 and 2015, respectively. We measured AMF colonization in soybean roots, soybean growth parameters such as aboveground plant biomass, $\mathrm{P}$ uptake at the flowering stage and grain yields at the maturity stage in both years. AMF community structure in soybean roots was characterized by specific amplification of small subunit (SSU) rDNA. 
Results: The increase in the root colonization at the flowering stage was small as a result of Papplication. Cover cropping did not affect the aboveground biomass and $\mathrm{P}$ uptake of soybean in both years, but the $\mathrm{P}$-application had positive effects on the soybean performance such as plant $\mathrm{P}$ uptake, biomass and grain yield in 2015. AMF communities colonizing soybean roots were also significantly influenced by P-application throughout the 2 years. Moreover, the diversity of AMF communities in roots was significantly influenced by P-application and cover cropping in both years, and was positively correlated with the soybean biomass, P uptake and grain yield throughout the two years.

Discussion: Our results indicated that P-application rather than cover cropping may be a key factor for improving soybean growth performance with respect to AMF diversity in P-limited cover cropping systems. Additionally, AMF diversity in roots can potentially contribute to soybean P nutrition even in the P-fertilized cover crop rotational system. Therefore, further investigation into the interaction of AMF diversity, P-application and cover cropping is required for the development of more effective P management practices on soybean growth performance.

\section{Introduction}

Phosphorus (P) application of synthetic fertilizers is often required to achieve high productivity due to strong interactions of $P$ with soil compounds such as iron and aluminium (Lynch, 2007). Additionally, increased application of synthetic fertilizers can lead to less active microbialmediated processes of mineralization and solubilization, and increase the potential risk of environmental pollution (Bai et al., 2013). The expected global peak in P production is also predicted to occur around 2030, whereas P demand is projected to increase (Cordell et al. 2009). Moreover, current global P reserves may be depleted in 50-100 years' time (Cordell et al., 2009). The global average cash production costs of phosphate rock in 1987 and 2017 increased from US $\$ 31$ to US \$99 per metric ton during this 30 year period (Global Economic Monitor Commodities 2017: http://databank.worldbank.org). Therefore, managing soil P availability is required to maintain agricultural crop production (Mishima et al., 2003).

Arbuscular mycorrhizal fungi (AMF) can increase host plant $\mathrm{P}$ uptake and growth, and 
AMF may especially improve plant P and micronutrients uptake (Smith \& Read, 2008). AMF also may act against the depletion of global P reserves (Gilbert, 2000). These nutritional benefits from AMF can be remarkably improved via appropriate agricultural managements (Kahiluoto et al., 2001, 2012; Gosling et al., 2006). Some species of the family Glomeraceae such as Funneliformis mosseae, Rhizophagus irregularis and family Gigasporaceae have been shown to have a positive impact on growth and nutrient uptake of plants under native and commercial AMF inoculated conditions (Verbruggen \& Kiers, 2010; Gosling et al., 2016). Also, previous studies have shown that $\mathrm{P}$ uptake via AMF is a distinct functional alternative to direct uptake by plants (Bucher, 2007), and the most of the P supplied by plants can be obtained via the mycorrhizal route (Smith et al., 2003).

According to a study by Johnson et al. (1993), there was a link between yield declines under continuous soybean cropping and the shift in AMF communities. Continuous cropping selects for the most rapidly growing and sporulating AMF species, which decreases crop performance over time. This abundance of detrimental AMF species leads to a decline in beneficial AMF species (Johnson et al., 1993). Furthermore, the introduction of mycorrhizal cover crops during winter season can be necessary for maintenance and increase indigenous AMF inoculum or diversity in soil and roots for subsequent crops (Higo et al., 2010, 2015a, 2016). Thus, the introduction of cover crops in temperate agricultural ecosystems, such as wheat, barley, oilseed rape or leguminous crops, including hairy vetch, red clover and white clover, reduces seasonal fallow and thus provides many benefits for subsequent crops and soil fertility (Karasawa \& Takahashi, 2015). In addition, a diverse AMF species composition and diversity can maximize the benefits from AMF (Maherali \& Klironomos, 2007; Powell et al., 2009). In turn, the diversity of AMF communities can contribute to plant P nutrition (van der Heijden et al., 1998; Verbruggen et al., 2013). Moreover, increasing AMF diversity in agroecosystems has been suggested to have the ability to boost crop growth, nutrient uptake and sustainability can be widespread (Hart \& Forsythe, 2012). The diversity of AMF communities can be influenced by agricultural management practices such as land-use type (Zhao et al., 2017), crop rotation (Higo et al., 2013, 2015a), tillage (Alguacil et al., 2008), fertilization (Xiang et al., 2016) and P- 
85

86

application (Kahiluoto et al., 2009, 2012; Wang et al., 2017). Recent studies have shown that the diversity of AMF communities in soils was not impacted (Jansa et al. 2014; Islas et al. 2016) or was decreased (Lin et al. 2012; Camenzind et al. 2014) by P-application. In addition, Papplication may decrease (Liu et al. 2012; Gosling et al. 2013) or not impact (Beauregard et al. 2013; Liu et al. 2016) AMF diversity in roots.

The yield and growth of soybeans under a P-unfertilized 4-year winter crop-soybean rotational system gradually has been found to decrease over time because of both a decrease in AMF colonization of soybeans and continuous nutrient removal from the soil by continuous crop rotations (Isobe et al., 2014). The same research group also found that there was a positive correlation between AMF colonization and soybean grain yield in a 4-year consecutive winter cover crop-soybean rotational system without $\mathrm{P}$ fertilizer, suggesting that higher AMF colonization can be a better solution for improving soybean growth and grain yield in the Plimited soil. Cover cropping alone would also appear not to supply enough P nutrition to recover soybean performance as much as the use of an alternative way of using moderate P-application in the consecutive P-unfertilized cover crop rotational system (Karasawa \& Takahashi, 2015). However, it still remains unclear which factor, such as P-application or cover cropping is driving increases in soybean performance via AMF benefits. Little is also known about how Papplication and cover cropping are linked to AMF benefits and soybean growth, and the effectiveness of AMF in cover crop-soybean rotational systems to improve the reliability and the robustness of the agricultural managements.

Therefore, we hypothesized that P-application or cover cropping in a P-limited soil would increase the diversity of AMF communities and the shift would be related to the soybean growth responses in the 5-year P-unfertilized cover crop study. Therefore, we approached this study with two objectives: First, to understand whether or not P-application and cover cropping impacts soybean growth performance. Second, to determine how AMF diversity in soybean roots is affected by P-application and cover cropping. 


\section{Experimental design}

114 We conducted a field trial of winter cover crop-soybean rotation at Nihon University, in

115 Kanagawa, Japan $\left(35^{\circ} 22^{\prime} \mathrm{N} 139^{\circ} 27^{\prime} \mathrm{E}\right)$. The soil at the field site is classified as a volcanic ash soil

116 (Allophonic andosol). According to the Japan Meteorological Agency

117 (http://www.jma.go.jp/jma/indexe.html) from 2000 to 2015, the climate is characterized by 118 relatively high temperatures and evenly distributed precipitation throughout the year. The

119 average temperature for the year in this area is around $16.2^{\circ} \mathrm{C}$. The average maximum

120 temperature and average minimum temperature is around $25.1^{\circ} \mathrm{C}$ and $7.7^{\circ} \mathrm{C}$, respectively. The 121 average precipitation for the year in this prefecture is around $1609.7 \mathrm{~mm}$.

122 We conducted our research onto two experimental phases. In the first phase, we applied cover cropping-soybean rotations without P-application. In the second phase, we applied the same cover crop-soybean rotation with or without P-application. The first cover crop experiment (2007 to 2012) comprised three winter cover crop treatments such as winter wheat (Triticum aestivum L.), red clover (Trifolium pratense L.), oilseed rape (Brassica napus L.) and fallow (Fig. 1). These three cover crop treatments are used to cover the soil surface during winter and the fallow period in annual cropping systems in temperate regions of Japan. They have also been used in rotation with summer crops, not only to promote soil biological/chemical fertility, but also to modify the physical properties of soil and to suppress weeds. There were three replicate plots per treatment arranged in a randomized complete block design. Each plot had an area of 9 $\mathrm{m}^{2}(4.5 \mathrm{~m} \times 2 \mathrm{~m})$. In this first phase, the experimental did not receive P fertilizers for over a 5year period. In the field plots used for the experiments, soybean (Glycine max (L.) Merr., cv: Enrei) had been cultivated to standardize soil biochemical conditions before the field trial started. As a preliminary investigation of soil chemical characteristics $(0-15 \mathrm{~cm}$ soil depth) at this experimental site in 2014 before the study of phase two (Fig. 1), the soil pH ranged from 6.0 to 6.1 and total organic carbon (C) was 5.6\% to $6.5 \%$, respectively. Total nitrogen $(\mathrm{N})$ and nitrate nitrogen content ranged from $0.41 \%$ to $0.48 \%$ and from 6.0 to $15.9 \mathrm{mg} \mathrm{kg}^{-1}$, respectively. Phosphate absorption coefficient ranged from 2320 to 2660. Further management details about the general information of the cover crop rotational system, seeding and sampling are presented 
141

142

143

144

145

146

147

148

149

150

151

152

153

154

155

156

157

158

in Higo et al. (2014).

In phase two of our experiment, the same three cover crops from the first experimental phase (wheat, red clover and oilseed rape) were sown in rows, with spacing of $30 \mathrm{~cm}$, in the cropped treatment on November 9, 2013, and November 18, 2014 except for red clover which was sown on March 16, 2015. Winter wheat (cv: Bandowase, mycorrhizal crop) seeds were sown at $200 \mathrm{~kg} \mathrm{ha}^{-1}$ with $\mathrm{N}$ (ammonium sulfate) and $\mathrm{K}$ (potassium chloride) application rates of 100 and $90 \mathrm{~kg} \mathrm{ha}^{-1}$, respectively. Oilseed rape seeds (cv: Michinokunatane, non-mycorrhizal crop) were sown at $30 \mathrm{~kg} \mathrm{ha}^{-1}$ with $\mathrm{N}$ and $\mathrm{K}$ application rates of 100 and $50 \mathrm{~kg} \mathrm{ha}^{-1}$, respectively. Red clover seeds (cv: Makimidori, mycorrhizal crop) were sown at $30 \mathrm{~kg} \mathrm{ha}^{-1}$ with $\mathrm{N}$ and $\mathrm{K}$ application rates of 30 and $50 \mathrm{~kg} \mathrm{ha}^{-1}$ in 2013 and 2015. The tops of the cover crops were cut close to the ground and removed on June 3, 2014, and June 16, 2015. In fallow, weeds were manually removed during the winter period.

We used a split plot design to divide the $4.5 \times 2 \mathrm{~m}$ of the cover crop experimental plots into $2.25 \times 2 \mathrm{~m}$ plots for the two $\mathrm{P}$ treatment plots (no P-application and P-application) of the phase two experiment (Fig. 1). Then, both no $\mathrm{P}$ and $\mathrm{P}$-application plots were replicated three times in $2.25 \times 2 \mathrm{~m}$ plots. The soybean (cv: Enrei) seeds were sown at a spacing of $60 \mathrm{~cm} \times 15 \mathrm{~cm}$ on June 17, 2014, and June 17, 2015. To obtain the soybean grain yield, soybeans in each treatment were collected at the maturity stage (R8 growth stage) in early to late October in both years. In 2014 and 2015, the $\mathrm{N}$ and $\mathrm{K}$ application rates were 30 and $50 \mathrm{~kg} \mathrm{ha}^{-1}$, respectively. In 2014, the amount of $\mathrm{P}$ (triple superphosphate) in the P-application plots was applied at $52.5 \mathrm{~kg} \mathrm{ha}^{-1}$ as a sub-optimal level. The P-application did not increase the available soil P in 2014 because of the high $\mathrm{P}$ absorption coefficient (around 2600). In 2015, the amount of $\mathrm{P}$ in the $\mathrm{P}$-application plots was applied at $157.5 \mathrm{~kg} \mathrm{ha}^{-1}$ to ovecome the high $\mathrm{P}$ absorption fixation into the soil it as a $\mathrm{P}$ regime for comparing with soybean growth performance with no P- and P-application. The amount of P-application was moderate and optimal to increase the available soil $\mathrm{P}$ in this study. The content of available soil P (Truog P) was measured according to Truog (1930). 
169 The soil samples were randomly taken from ten points in each replicate and pooled to one

170

171

172

173

174

175

176

177

178

179

180

181

182

183

184

185

composite sample on June 17, 2014, and June 17, 2015, respectively. Soybean root samples were taken at the full bloom stage (R2 growth stage) on July 31, 2014 (44 days after planting), and August 6, 2015 (50 days after planting). The full bloom stage corresponds to the stage when the mycorrhizal colonization of soybean roots is usually at its highest (Zhang et al., 1995). In each rotation, the root samples were randomly collected from ten plants (to a depth of $15 \mathrm{~cm}$, the diameter of $20 \mathrm{~cm}$ ) per replicate. The root samples were collected from the soil sample and maintained at $-80^{\circ} \mathrm{C}$ for DNA extraction and measurement of $\mathrm{AMF}$ colonization. The root samples were stained with a 5\% (w/v) black ink-vinegar solution (Vierheilig et al., 1998), and the AMF colonization in the soybean roots was measured as described by Giovannetti \& Mosse (1980).

\section{Analysis of plant $P$ and measurement of soybean grain yield}

The aboveground plant parts of the ten soybean plants were cut close to the ground at the full bloom stage and were randomly sampled on July 31, 2014, and August 6, 2015. To obtain the soybean grain yield, ten soybean samples per plot in each treatment were collected at maturity stage in early to late October in both years. The aboveground soybean plant biomass and plant length were measured in all plots. The aboveground plant biomass and $\mathrm{P}$ uptake by soybeans were determined after the samples were oven dried at $80^{\circ} \mathrm{C}$ for $48 \mathrm{~h}$. The $\mathrm{P}$ uptake was determined using the molybdenum yellow colorimetric method (Murphy \& Riley, 1962).

\section{DNA extraction and nested polymerase chain reaction (PCR)}

Total genomic DNA was extracted from $150 \mathrm{mg}$ of fresh root samples using the DNeasy Plant Mini Kit (Qiagen, Hilden, Germany) according to the manufacturer's instructions. The genomic DNA pellet was stored at $-30^{\circ} \mathrm{C}$ until use in the nested PCR. The fragments in the fungal small subunit ribosomal DNA (SSU rDNA) were amplified using nested PCR method (Liang et al., 2008). The universal eukaryotic primer NS31 (forward) (5'- TTGGAGGGCAAGTCTGGTGCC3') (Simon et al., 1992) and the fungus-specific primer AM1 (reverse) (5'- 
197

198

199

200

201

202

203

204

205

206

207

208

209

210

211

212

213

214

215

216

217

218

219

220

221

222

223

224

GTTTCCCGTAAGGCGCCGAA-3') (Helgason et al., 1998) were used in the first PCR to amplify the 5' end of the SSU rDNA region for comprehensive taxon sampling for the Glomeromycota (Schüßler et al., 2001a,b). Three subsamples per plot were amplified in a $20-\mu 1$ reaction mixture containing $2 \mu \mathrm{l}$ of 10 -fold genomic DNA (around 1 to $5 \mathrm{ng} / \mu \mathrm{l}$ ), $0.2 \mu \mathrm{M}$ of each primer and $2 \times$ GoTaq Green Master Mix (Promega, Madison, WI, USA) using a Mastercycler ep Gradient (Eppendorf, Hamburg, Germany). The PCR condition was composed of initial treatment at $94^{\circ} \mathrm{C}$ for $1 \mathrm{~min} ; 30$ cycles at $94^{\circ} \mathrm{C}$ for $1 \mathrm{~min}, 66^{\circ} \mathrm{C}$ for $1 \mathrm{~min}$ and $72^{\circ} \mathrm{C}$ for $90 \mathrm{~s}$; and a final extension at $72^{\circ} \mathrm{C}$ for $10 \mathrm{~min}$. The first PCR products were diluted 10 -fold and used as templates for the second PCR using the nested primers NS31-GC (forward) (5'-

CGCCCGGGGCGCGCCCCGGGCGGGGCGGGGGCACGGGGGTTGGAGGGCAAGTCTG GTGCC-3') (Kowalchuk et al., 2002) and Glo1 (reverse) (5'-GCCTGCTTTAAACACTCTA-3') (Cornejo et al., 2004). Three subsamples per plot were amplified in a $20-\mu 1$ reaction mixture containing $2 \mu \mathrm{l}$ of 10 -fold 1 st PCR amplicons, $0.2 \mu \mathrm{M}$ of each primer and $2 \times$ GoTaq Green Master Mix (Promega, Madison, WI, USA) using a Mastercycler ep Gradient (Eppendorf). The PCR protocol was composed of initial treatment at $95^{\circ} \mathrm{C}$ for $5 \mathrm{~min} ; 35$ cycles at $94^{\circ} \mathrm{C}$ for $45 \mathrm{~s}$, $52^{\circ} \mathrm{C}$ for $45 \mathrm{~s}$ and $72^{\circ} \mathrm{C}$ for $1 \mathrm{~min}$; and a final extension at $72^{\circ} \mathrm{C}$ for $30 \mathrm{~min}$. Gel electrophoresis separated amplification products on 1\% agarose gel, and the approximately $250 \mathrm{bp}$ DNA amplicons were visualized by staining with ethidium bromide.

\section{PCR-denaturing gradient gel electrophoresis (DGGE)}

Three independent PCR products were pooled together, and then $20 \mu \mathrm{L}$ of the nested PCR product was subsequently analyzed by DGGE on a DCode Universal Mutation Detection System (Bio-Rad Laboratories, Piscataway, NJ, USA). Standard DNA markers were created by individually PCR-amplifying DNA extracted from root samples by Higo et al. (2015b). The PCR-DGGE condition was based on the method of Higo et al. (2015b). The gels containing 6.5\% acrylamide were poured with a gradient of 35-55\% denaturant. All DGGE analyses were performed in a $1 \times \mathrm{TAE}$ buffer at a constant temperature of $55^{\circ} \mathrm{C}$ at $50 \mathrm{~V}$ for $60 \mathrm{~min}$, followed by $50 \mathrm{~V}$ for $960 \mathrm{~min}$. The gels were stained with SYBR Green diluted in $1 \times$ TAE buffer $(1: 10,000)$ 
225

226

227

228

229

230

231

232

233

234

235

236

237

238

239

240

241

242

243

244

245

246

247

248

249

250

251

252

for 20 min, UV illuminated and digitally photographed (Figs. S1 and S2). Pictures were digitized by Phoretix 1D Pro (Nonlinear Dynamics Ltd., Newcastle upon Tyne, UK). We calculated Shannon index $\left(H^{\prime}\right)$ from these data, expressed by the number of DGGE bands in each root sample. Fromin et al. (2002) and Schneider et al. (2015) mentioned that visual observation of the DGGE gel revealed the presence of multiple bands in all samples (a band represents a distinct taxon in theory).

\section{Quantification of specific root AMF taxa using a quantitative real-time PCR (qPCR)}

The abundance of six-selected typical AMF taxa including Rhizophagus irregularis, Funneliformis mosseae, Claroideoglomus claroideum, Gigaspora margarita, Cetraspora pellucida and Diversispora celata was measured using qPCR with taxon-specific primers and hydrolysis (TaqMan) probes targeting large ribosomal subunit DNA (LSU rDNA) genes (Wagg et al., 2011; Thonar et al., 2012). The partial LSU rDNA genes of $R$. irregularis, F. mosseae, $C$. claroideum, G. margarita and Ce. pellucida followed the method described by Thonar et al. (2012). We also used the method described by Wagg et al. (2011) to quantify Diversispora celata. Each PCR sample contained a total volume of $10 \mu \mathrm{L}$ that consisted of $2 \mu \mathrm{L}$ water, 400 $\mathrm{nM}$ each of forward primer and reverse primer, $100 \mathrm{nM}$ TaqMan probe and $2 \times$ FastStart TaqMan Probe Master Mix $+2 \mu \mathrm{L}$ of 10-diluted genomic DNA. The qPCR was carried out using a LightCycler 96 (Roche Diagnostics, Rotkreuz, Switzerland). The qPCR cycling conditions were as follows: initial denaturation at $95^{\circ} \mathrm{C}$ for $15 \mathrm{~min}$, followed by 45 cycles with denaturation at $95^{\circ} \mathrm{C}$ for $10 \mathrm{~s}$ and annealing at the optimized temperature for each primer/probe combination for $30 \mathrm{~s}$ and elongation at $72^{\circ} \mathrm{C}$ for $1 \mathrm{~s}$.

\section{Statistical analysis}

We used an arcsine-square root transformation to normalize the data of AMF colonization in the soybean. The available soil P, growth parameters and AMF diversity data were transformed using a natural logarithm. The abundance of AMF tax was $\log (\mathrm{x}+1)$ transformed to reduce heteroscedasticity in the data. First, a generalized linear model (GLM) was used to determine the 
253

254

255

256

257

258

259

260

261

262

263

264

265

266

267

268

269

270

271

272

273

274

275

276

277

278

279

280

effects of P-application and cover cropping and their interactions on each parameter in this study of a split plot design in R 3.3.2. Next, differences among means, where analysis of variance (ANOVA) was significant, were assessed using Tukey's honestly significant difference (HSD) test $(P$-values $<0.05)$ using the multcomp package in R 3.3.2. Data for the significance of differences between P-application treatments among cover crop systems were assessed using Student's t-test.

A permutational multivariate analysis of variance (PERMANOVA) was performed using the vegan package in $\mathrm{R}$ to investigate the effect of $\mathrm{P}$-application and cover crop systems on AMF community structure (Hammer et al., 2001). To analyze the relationship of cover cropping and Papplication with respect to AMF community structures (AMF communities), a redundancy analysis (RDA) (gradient length $<4$ ) was performed as the multivariate analysis using the vegan package in $\mathrm{R}$ 3.3.2. The presence/absence data matrix was composed of the abundance of DGGE bands and cover crop management or P-application. The environmental variable of cover cropping and P-application was coded as a dummy variable (0 and 1). Goodness-of-fit statistics $\left(R^{2}\right)$ of measured factors fitted to the RDA ordination of the AMF community were calculated using the envfit function in the vegan package with $P$-values based on 999 permutations (Oksanen, 2017). To investigate if AMF community structure differed significantly between Papplication or cover crop management, the PERMANOVA was performed with 999 permutations using the adonis function in the vegan package in $\mathrm{R}$.

The network graph included the correlation coefficients between soybean growth performance and AMF parameters using the igraph package in $\mathrm{R}$, and then the network graph was described using Cytoscape for visualizing complex networks (www.cytoscape.org/). In this model, the AMF taxa abundance was represented by the scores of the first component of the PCA in this study. Pearson's correlation coefficient $(r)$ was expressed as the indication of the strength of the connections.

\section{Results}

Available soil $P$ and AMF colonization 
281 In this study, the P-application in 2014 did not change the available soil P regardless of cover

282

283

284

285

286

crop systems, whereas a significant difference was found in the available soil $\mathrm{P}$ in all of the cover crop systems compared with the no P-application plots in 2015 (Fig. 2A).

Overall, the AMF colonization in the soybean regardless of P-application and cover crop systems was never greater than 20\% (Fig 2B). In the no P-application plots, cover cropping affected the AMF colonization at the R2 stage in 2014 and 2015 (Fig. 2B). In 2014 and 2015, the AMF colonization under wheat and red clover treatments with no P-application plots tended to be higher than that of oilseed rape and fallow with no P-application plots. Contrary to the results of the no P-application plots, the AMF colonization in all of the cover cropping treatments with P-application was at a similar level. This similar tendency in AMF colonization with regard to cover cropping was observed between 2014 and 2015. Overall, our results showed that the cover cropping contributed to the AMF colonization in the soybean roots only for no P-application plots, whereas P-application eliminated differences in AMF colonization due to cover cropping.

\section{Plant growth, $P$ uptake and grain yield}

According to Figure $3 \mathrm{~A}$, the aboveground plant biomass in soybeans at the R2 stage did not vary among cover crop systems in both 2014 and 2015. In 2014 and 2015, the aboveground plant biomass under wheat and fallow treatments with no P-application plots tended to be higher than that of red clover and oilseed rape treatments with no P-application plots. In 2015, but not 2014, P-application plots, the aboveground plant biomass of soybeans was more than double than those of the no P-application plots. The aboveground biomass for the P-and no P-application plots were significantly different for red clover (2015), oilseed rape (2014 and 2015), and fallow (2014 and 2015).

Our results as shown in Fig. 3B revealed that cover cropping did not have a significant effect on the plant P uptake of soybeans regardless of the P-application plots. However, the plant P uptake in soybeans was significantly increased by the P-application in 2014 and 2015. Moreover, there was a significant difference in the plant $\mathrm{P}$ uptake between the P- and no Papplication plots for fallow in 2014 and 2015. In 2014 and 2015, the plant P uptake under wheat 
309

310

311

312

313

314

315

316

317

318

319

320

321

322

323

324

325

326

327

328

329

330

331

332

333

334

335

336

and fallow treatments with no P-application plots tended to be higher than that of red clover and oilseed rape with no P-application plots. Contrary to the results of the no P-application plots, the plant $\mathrm{P}$ uptake in all of the cover cropping treatments with P-application was inconsistent between 2014 and 2015. The plant P uptake in oilseed rape and fallow treatments was higher than compared with wheat and red clover treatments in 2014. However, in 2015, the plant P uptake was at a similar level in wheat, oilseed rape and fallow, but the plant $\mathrm{P}$ uptake in red clover treatment was lowest throughout the 2-year study.

We found that the grain yield in soybeans was influenced by the cover crop systems only in 2014 (Fig. 3C). The grain yield in fallow treatment was highest among the cover crop treatments without P-application in both years. The P-application had a significant effect on the grain yield of soybean in both 2014 and 2015. The soybean grain yields at the P-application plots in the experiment were more than double in both 2014 and 2015. We also found that there were significant differences in the grain yield between the P-and no P-application plots for red clover (2014 and 2015) and oilseed rape (2015) managements.

\section{Diversity of AMF communities and taxa abundance in the roots of soybean}

The diversity index $\left(H^{\prime}\right)$ in soybeans at the R2 stage were significantly influenced by Papplication and cover cropping in both 2014 and 2015 (Fig. 4). The $H^{\prime}$ ' in oilseed rape and fallow treatments regardless of P-application and cover cropping was higher than compared with wheat and red clover treatments, although oilseed rape and fallow are non-mycorrhizal cover cropping. This tendency was opposite to that found for the AMF colonization of soybeans. Additionally, Papplication stimulated $H^{\prime}$ in all cover cropping treatments in both years. The $H^{\prime}$ in the Papplication plots regardless of cover crop treatments was higher than that of the no P-application plots.

Our results showed that the six-selected AMF taxa were not influenced by cover cropping in 2014 (Table 1). However, the P-application had a significant effect on the abundance of all sixselected AMF taxa in 2014. The abundance of five AMF taxa in the P-application plots tended to be higher than those of the no P-application plots regardless of the cover crop systems. By 
337

338

339

340

341

342

343

344

345

346

347

348

349

350

351

352

353

354

355

356

357

358

359

360

361

362

363

364

contrast, in 2015, the abundance of $R$. irregularis in the P-application plots significantly decreased compared with that in the no P-application plots for wheat, red clover, and oilseed rape. Ce. pellucida also decreased but only in oilseed rape treatment. The abundance of the other AMF taxa was not affected by P-application. As in 2014, there was no significant effect of cover cropping on any taxa.

\section{Relationships among AMF communities, cover cropping, and P-application}

We used a redundancy analysis (RDA) to identify the relationships among AMF communities in soybean roots with cover crop management and P-application (Fig 5A and B). In 2014 and 2015, the RDA trends clearly showed that the P-application noticeably altered the AMF community structure in the soybean roots. In 2014, the ordination diagram indicates that oilseed rape $\left(R^{2}=\right.$ $0.756, P=0.001$ ) contributed significantly to the variation in AMF root communities (Fig. 5A). However, wheat $\left(R^{2}=0.095, P=0.349\right)$, red clover $\left(R^{2}=0.138, P=0.191\right)$ and fallow $\left(R^{2}=\right.$ $0.040, P=0.630$ ) did not contribute to the variation in the AMF root communities. Additionally, the P-application treatment $\left(R^{2}=0.801, P=0.001\right)$ and no P-application treatment $\left(R^{2}=0.801, P\right.$ $=0.001)$ contributed to the variation in the AMF root communities. In 2015, the ordination diagram indicates that red clover $\left(R^{2}=0.704, P=0.001\right)$ contributed significantly to the variation in the AMF root communities (Fig 5B). However, wheat $\left(R^{2}=0.154, P=0.181\right)$, oilseed rape $\left(R^{2}=0.129, P=0.255\right)$ and fallow $\left(R^{2}=0.173, P=0.141\right)$ did not contribute to the variation in the AMF root communities. Furthermore, the P-application treatment $\left(R^{2}=0.743, P\right.$ $=0.001)$ and no P-application treatment $\left(R^{2}=0.743, P=0.001\right)$ contributed to the variation in the AMF root communities. A PERMANOVA was also carried out to examine the relative importance of each agricultural management for the AMF root communities. The PERMANOVA showed that P-application significantly affected the AMF root community structure (2014: $F=4.263, P=0.001,2015: F=4.226, P=0.001$ ), but cover crop management did not impact the AMF root communities (2014: $F=1.193, P=0.189,2015: F=1.669, P=$ 0.057). 
365

366

367

368

369

370

371

372

373

374

375

376

377

378

379

380

381

382

383

384

385

386

387

388

389

390

391

392

\section{Response of soybean growth to AMF parameters}

In the soybean growth response, the relationships between available soil $\mathrm{P}$ and soybean growth performance was not linear in the cropping system with no P-application (Fig. 6A-C). The difference in the soybean growth performance was small with no P-application. The relationships between available soil $\mathrm{P}$ and soybean growth performance such as plant biomass $(r=0.874)$, plant P uptake $(r=0.821)$ and grain yield $(r=0.801)$ was significantly linear in the cropping system with P-application. With the AMF contributions to soybean growth performance, the relationships between AMF colonization and soybean growth was not linear in the cropping system with and without P-application (Fig. 6D-F). The P-application significantly improved the linear relationships between the diversity index and soybean growth performance (Fig. 6G-I). The relationships between the diversity index and soybean growth performance such as plant biomass $(r=0.967)$, plant P uptake $(r=0.967)$ and grain yield $(r=0.928)$ was positively correlated in the cropping system with P-application.

To understand the role of AMF parameters on soybean performance and how they link to the available soil $\mathrm{P}$ and soybean growth, we used a network analysis to identify the relationships between AMF parameters in soybean roots and soybean growth in this study (Fig. 7). The results showed the same tendency with the linear analysis in the 2-year experiment. The relationships between the diversity index and available soil $\mathrm{P}$ were related to the soybean growth performance such as plant P uptake, plant biomass, and grain yield. However, each AMF taxa abundance and AMF colonization were not related to the soybean growth responses, especially grain yield, throughout the experiment.

\section{Discussion}

\section{Impact of $\mathbf{P}$-application and cover cropping on colonization}

It is well known that cultivation of preceding crops or fallow as well as P-application impacts AMF colonization of subsequent crops (Karasawa et al., 2002; Karasawa \& Takebe, 2012; Isobe et al., 2014). Mycorrhizal cover crops or oilseed rape slightly increased AMF colonization of subsequent soybean compared with fallow as a control (Fig. 2B), in agreement with previous 
393

394

395

396

397

studies (Karasawa et al., 2002; Karasawa \& Takebe, 2012; Isobe et al., 2014). Some studies also reported that Brassicaceae plants decreased colonization in subsequent crops during just early growth stages compared with mycorrhizal crops (Gavito \& Miller, 1998; Sorensen et al., 2005). Thus, the cultivation of oilseed rape in a rotation with soybean during the winter period may not have necessarily interfered with AMF colonization of subsequent soybean in this study.

In addition, AMF colonization is inhibited under high P-application (Kahiluoto et al., 2001; Balzergue et al., 2011). Plants can fail to react to AMF when available soil P is extremely low (Ryan et al., 2002). Miranda \& Harris (1994) also reported that deficiency of available soil P inhibited AMF colonization. On the contrary, Gosling et al. (2013) indicated that there was no significant decrease in AMF colonization in soybeans under high P availability in soil. Plants can control AMF colonization depending on their nutritional status (Smith \& Read, 2008) as well as under high soil P conditions. Bolan et al. (1984) also reported that a moderate amount of Papplication in P-limited soils might increase AMF colonization and benefits such as $\mathrm{P}$ availability for crop growth performance. Our results indicated that there was no effect of cover cropping on AMF colonization in soybeans under $\mathrm{P}$ application, but cover cropping only increased AMF colonization when P was not applied (Fig. 2B). Thus, one possible reason for higher AMF colonization in P-application may be that the P-application may possibly stimulate potential AMF activities such as hyphal growth to colonize soybean roots by improving $\mathrm{P}$ fertility that prefers AMF in the soil.

\section{Impact of P-application and cover cropping on the diversity of root AMF communities}

Previous studies have reported that $\mathrm{P}$ fertilization had no significant effect on the diversity of AMF in maize roots and its rhizosphere soils under a long-term field experiment (Liu et al., 2016; Wang et al., 2017). On the contrary, Lin et al. (2012) found that chemical fertilizers decreased AMF diversity in a long-term field experiment. Moreover, Gosling et al. (2013) reported that the AMF community diversity in soybean roots decreased due to the high availability of soil $\mathrm{P}$ in a field study. In addition, plants can directly gain enough nutrients from the soil in a nutrient-rich environment without benefit from AMF. As a result, the diversity of 
421

422

423

424

425

426

427

428

429

430

431

432

433

434

435

436

437

438

439

440

441

442

443

444

445

446

447

448

AMF communities can also decrease (Liu et al., 2015). Surprisingly, our results indicated that the diversity of AMF communities in soybeans, regardless of cover crop management, tended to increase as a result of P-application (Fig. 4), in disagreement with our hypothesis. Also, the shift of AMF communities was obvious from the results of RDA trends that showed that the Papplication changed the AMF community structure in the soybean roots rather than the cover crop systems (Fig. 5). Wakelin et al. (2012) and Maček et al. (2011) implied that abiotic selective pressures such as soil fertility determine the AMF community structure. The observed increase in AMF diversity as a result of P-application can be linked to the degree of selective pressure for mycorrhization in soybean roots. Some P-unresponsive taxa may have been dominant in the experimental field under the cover crop rotational system. Increasing the available soil P can decrease the selective pressure, and this could increase the opportunity for P-responsive species to establish soybean roots. Thus, one possible explanation for this result was that the activity of AMF could have been inhibited due to soil P depletion of the P-unfertilized 5-year continuous crop rotational system. This could be one reason why P-application increased the AMF diversity of soybean crops.

Furthermore, we found that cover cropping did not impact the AMF root communities in soybeans from the result of PERMANOVA (Fig. 5). The P-application eliminated the effect of cover cropping in both AMF colonization and diversity in the roots of subsequent soybeans. Turrini et al. (2016) and Higo et al. (2018) indicated that a shift in indigenous AMF communities in the subsequent maize roots was independent of cover crop identity and diversity. Higo et al. (2014) also found that cover crop rotations did not impact AMF communities in the roots of subsequent soybean. However, rotation year affected the AMF communities in soybean roots suggesting that climate or other environmental conditions were more imperative than cover crop management. Therefore, the P-application may have influences on AMF communities in soybean roots, suggesting that fertilizer application or other factors such as soil chemical properties and other environmental factors can be more important than cover cropping. This was the case of $R$. irregularis in the soybean as our study found that its abundance was influenced by P-application, but not by cover cropping in this study. 


\section{Impact of P-application and cover cropping on the abundance of root AMF taxa}

451 Previous studies have reported that AMF have different niches and are well known to prefer to

452

453

454

455

456

457

458

459

460

461

462

463

464

465

466

467

468

469

470

471

472

473

474

475

476

inhabit different soils (Johnson 1993). Moreover, fertilization may directly favor species that grow better in enriched soils (Dumbrell et al., 2010). Wakelin et al. (2012) have reported that $R$. irregularis decreased as a component of the AMF communities with increasing available soil P, in agreement with our study (Table 1). The fluctuation in abundance of AMF taxa as a result of P-application could link to the preference of fertilization or inhabiting soil conditions among AMF in soybean roots. $R$. irregularis has been observed in a different type of lands, and can have an ability of high tolerance for environmental factors due to a strategy of life history as a generalist (Börstler et al., 2008). Thus, it is likely that the $R$. irregularis may tolerate under the low-P soil conditions in this cover crop rotational system.

\section{Impact of P-application and cover cropping on the soybean performance}

According to a study by Jansa et al. (2008), the growth of Allium porrum with three inoculated AMF species (F. mosseae, C. claroideum, and R. irregularis) was enhanced compared to that of A. porrum when each AMF species was mono-inoculated. Similarly, in the results of network analysis and growth response of soybean to AMF parameters, we found that the aboveground plant $\mathrm{P}$ and biomass of soybeans during the R2 stage and the grain yield of soybeans were positively correlated with the AMF diversity in the roots of soybeans with P-application (Figs. 6 and 7). Gosling et al. (2016) also reported that increased benefit from high AMF diversity on the growth of Allium cepa was found compared to mono-inoculated. On the other hand, no positive correlations were observed between AMF colonization and soybean grain yield regardless of Papplication (Figs. 6 and 7), in disagreement with a previous study (Isobe et al., 2014). One possible explanation may be that a moderate amount of P-application in P-limited soils may increase root colonization and benefits such as $\mathrm{P}$ availability for crop growth performance (Bolan et al., 1984). The increase of AMF colonization with P-application was only slight (i.e., under $20 \%$ ), and the increase may be related to the direct response of soybeans to increasing $\mathrm{P}$ 
477

478

479

480

481

482

483

484

485

availability that might obscure the response according to the increased AMF colonization.

Furthermore, the AMF communities were assessed by only flowering seasons and crop phenology may be important for the shift of AMF communities. We simply did not take any samples at different crop growth stages and future studies examining according to different crop phenology would be needed to better understand the relationships between crop phenology and AMF diversity with P-application.

Furthermore, the introduction of cover crops can increase the amount of carbon, such as organic matter, to serve as an energy source for biological activity (Jokela et al., 2009). In this study, our cover crop systems did not improve growth performance such as plant biomass and $\mathrm{P}$ uptake of soybean at the full bloom stage (Figs. 3 and 7). In fact, cover cropping decreased grain yield of soybeans without P-application in 2014 compared with fallow, whereas the Papplication enhanced the growth and yield of soybeans. There is one possible reason why cover cropping did not improve soybean growth performance. That may be due to the continuous nutritional removal in the 5-year P-unfertilized crop rotational system because the top dry matters of cover crops were not incorporated into the soil. Therefore, further investigation into the relationships among AMF diversity, P-application and cover cropping on soybean growth performance would be required to gain more benefit from AMF in cover crop rotational systems.

\section{Conclusions}

The main conclusions from this experiment are that P-application was more important than cover cropping in AMF communities and soybean growth performance under $\mathrm{P}$ deficit conditions (in fact, P-application seems to eliminate the effect of cover cropping in both AMF colonization and diversity). In addition, P-application can have beneficial effects on the diversity of AMF communities in the P-unfertilized continuous crop rotational system. These differences in the AMF communities may relate to soybean productivity and P-use efficiency in cover crop rotational systems. Additionally, a higher diversity of AMF communities found in soybean roots with P-application can contribute to the potential for P uptake and growth under winter cover crop rotations with soybean. Thus, these results indicated that the soybean performance could be 
505

506

507

508

509

510

511

512

513

514

515

516

517

518

519

520

521

522

523

524

525

526

527

528

529

530

531

532

partially related to the interaction of P-application with AMF diversity. However, we still need to investigate how to improve agronomic benefits from AMF diversity associated with soybean plants, which will give useful information on appropriate $\mathrm{P}$ management and cover crop choices in cover crop rotational systems.

\section{References}

Alguacil MM, Lozano Z, Campoy MJ, Roldán A. 2010. Phosphorus fertilisation management modifies the biodiversity of AM fungi in a tropical savanna forage system. Soil Biology and Biochemistry 42(7):1114-1122

Alguacil MM, Lumini E, Roldán A, Salinas-García JR, Bonfante P, Bianciotto V. 2008. The impact of tillage practices on arbuscular mycorrhizal fungal diversity in subtropical crops. Ecological Application 18(2):527-36

Bai Z, Li H, Yang X, Zhou B, Shi X, Wang B, Li D, Shen J, Chen Q, Qin W, Oenema O, Zhang F. 2013. The critical soil P levels for crop yield, soil fertility and environmental safety in different soil types. Plant and Soil 372(1-2):27-37

Balzergue C, Puech-Pagès V, Bécard G, Rochange SF. 2011. The regulation of arbuscular mycorrhizal symbiosis by phosphate in pea involves early and systemic signalling events. Journal of Experimental Botany 62(3):1049-1060

Beauregard MS, Gauthier MP, Hamel C, Zhang T, Welacky T, Tan CS, St-Arnaud M. 2013. Various forms of organic and inorganic $\mathrm{P}$ fertilizers did not negatively affect soil-and rootinhabiting AM fungi in a maize-soybean rotation system. Mycorrhiza 23(2): 143-154

Bolan NS, Robson AD, Barrow NJ. 1984. Increasing phosphorus supply can increase the infection of plant-roots by vesicular arbuscular mycorrhizal fungi. Soil Biology and Biochemistry 16(4):419-420

Börstler B, Raab PA, Thiery O, Morton JB, Redecker D. 2008. Genetic diversity of the arbuscular mycorrhizal fungus Glomus intraradices as determined by mitochondrial large subunit rRNA gene sequences is considerably higher than previously expected. New Phytologist 180(2): 452-465 
533

534

535

536

537

538

539

540

541

542

543

544

545

546

547

548

549

550

551

552

553

554

555

556

557

558

559

560

Bucher M. 2007. Functional biology of plant phosphate uptake at root and mycorrhiza interfaces. New Phytologist 173(1):11-26

Camenzind T, Hempel S, Homeier J, Horn S, Velescu A, Wilcke W, Rillig MC. 2014. Nitrogen and phosphorus additions impact arbuscular mycorrhizal abundance and molecular diversity in a tropical montane forest. Global Chang Biology 20(12):3646-3659

Cordell D, Drangert JO, White S. 2009. The story of phosphorus: global food security and food for thought. Global Environmental Change 19(2):292-305

Cornejo P, Azcón-Aguilar C, Miguel Barea J, Ferrol N. 2004. Temporal temperature gradient gel electrophoresis (TTGE) as a tool for the characterization of arbuscular mycorrhizal fungi. FEMS Microbiology Letters 241(2):265-270

Dumbrell AJ, Nelson M, Helgason T, Dytham C, Fitter AH. 2010. Relative roles of niche and neutral processes in structuring a soil microbial community. ISME Journal 4:337-345

Fromin N, Hamelin J, Tarnawski S, Roesti D, Jourdain-Miserez K, Forestier N, Teyssier-Cuvelle S, Gillet F, Aragno M, Rossi P. 2002. Statistical analysis of denaturing gel electrophoresis (DGE) fingerprinting patterns. Environmental Microbiology 4(11):634-643

Gavito ME and Miller MH. 1998. Early phosphorus nutrition, mycorrhizae development, dry matter partitioning and yield of maize. Plant and Soil 199(2):177-186

Gilbert GA, Knight JD, Vance CP, Allan DL. 2000. Proteoid root development of phosphorus deficient lupin is mimicked by auxin and phosphonate. Annals of Botany 85(6):921-928

Giovannetti M, Mosse B. 1980. An evaluation of techniques for measuring vesicular-arbuscular mycorrhizal infection in roots. New Phytologist 84(3):489-500

Global Economic Monitor Commodities 2017. http://databank.worldbank.org

Gosling P, Hodge A, Goodlass G, Bending GD. 2006. Arbuscular mycorrhizal fungi and organic farming. Agriculture, Ecosystems and Environment 113(1-4):17-35

Gosling P, Mead A, Proctor M, Hammond JP, Bending GD. 2013. Contrasting arbuscular mycorrhizal communities colonizing different host plants show a similar response to a soil phosphorus concentration gradient. New Phytologist 198(2):546-556 
561 Gosling P, Jones J, Bending GD. 2016. Evidence for functional redundancy in arbuscular mycorrhizal fungi and implications for agroecosystem management. Mycorrhiza 26(1):7783

564

Hammer Ø, Harper DAT, Ryan PD. 2001. PAST-Palaeontological statistics software package for education and data analysis. Palaeontologia Electronica 4(1):1-9

Hart MM, Forsythe JA. 2012. Using arbuscular mycorrhizal fungi to improve the nutrient quality of crops; nutritional benefits in addition to phosphorus. Scientia Horticulturae 148:206-214

Helgason T, Daniell TJ, Husband R, Fitter AH, Young JPW. 1998. Ploughing up the wood-wide web? Nature 394:431

Higo M, Isobe K, Drijber RA, Kondo K, Yamaguchi M, Takeyama S, Suzuki Y, Niijima D, Matsuda Y, Ishii R, Torigoe Y. 2014. Impact of a 5-year winter cover crop rotational system on the molecular diversity of arbuscular mycorrhizal fungi colonizing roots of subsequent soybean. Biology and Fertility of Soils 50(6):913-926

Higo M, Isobe K, Kang DJ, Ujiie K, Drijber RA, Ishii R. 2010. Inoculation with arbuscular mycorrhizal fungi or crop rotation with mycorrhizal plants improves the growth of maize in limed acid sulfate soil. Plant Production Science 13(1):74-79

Higo M, Isobe K, Kondo T, Yamaguchi M, Takeyama S, Drijber RA, Torigoe Y. 2015a. Temporal variation of the molecular diversity of arbuscular mycorrhizal communities in three different winter cover crop rotational systems. Biology and Fertility of Soils 51(1):2132

Higo M, Isobe K, Matsuda Y, Ichida M, Torigoe Y. 2015b. Influence of sowing season and host crop identity on the community structure of arbuscular mycorrhizal fungi colonizing roots of two different gramineous and leguminous crop species. Advances in Microbiology 5(2):107-116

Higo M, Isobe K, Miyazawa Y, Matsuda Y, Drijber RA, Torigoe Y. 2016. Molecular diversity and distribution of indigenous arbuscular mycorrhizal communities colonizing roots of two different winter cover crops in response to their root proliferation. Journal of Microbiology 54(2):86-97 
Higo M, Isobe K, Yamaguchi M, Drijber RA, Ishii R. 2013. Diversity and vertical distribution of indigenous arbuscular mycorrhizal fungi under two soybean rotational systems. Biology and Fertility of Soils 49(8):1085-1096

Higo, M, Takahashi Y, Gunji K, Isobe K. 2018. How are arbuscular mycorrhizal associations related to maize growth performance during short-term cover crop rotation?". Journal of the Science of Food and Agriculture 98(4):1388-1396

Islas AT, Guijarro KH, Eyherabide M, Rozas HS, Echeverría HE, Covacevich F. 2016. Can soil properties and agricultural land use affect arbuscular mycorrhizal fungal communities indigenous from the Argentinean Pampas soils? Applied Soil Ecology 101:47-56

Isobe K, Higo M, Kondo T, Sato N, Takeyama S, Torigoe Y. 2014. Effect of winter crop species on arbuscular mycorrhizal fungal colonization and subsequent soybean yields. Plant Production Science 17(3):260-267

Jansa J, Smith FA, Smith SE. 2008. Are there benefits of simultaneous root colonization by different arbuscular mycorrhizal fungi?. New Phytologist 177(3):779-789

Jansa J, Erb A, Oberholzer HR, Šmilauer P, Egli S. 2014. Soil and geography are more important determinants of indigenous arbuscular mycorrhizal communities than management practices in Swiss agricultural soils. Molecular Ecology 23(8):2118-2135

Johnson NC. 1993. Can fertilization of soil select less mutualistic mycorrhizae? Ecological Application 3(4): 749-757

Jokela WE, Grabber JH, Karlen DL, Balser TC, Palmquist DE. 2009. Cover crop and liquid manure effects on soil quality indicators in a corn silage system. Agronomy Journal 101(4):727-737

Kahiluoto H, Ketoja E, Vestberg M, Saarela I. 2001. Promotion of AM utilization through reduced P fertilization 2. Field studies. Plant and Soil 231(1):65-79

Kahiluoto H, Ketoja E, Vestberg M. 2009. Contribution of arbuscular mycorrhiza to soil quality in contrasting cropping systems. Agriculture Ecosystems and Environment 134(1-2):36-45

Kahiluoto H, Ketoja E, Vestberg M. 2012. Plant-available P supply is not the main factor determining the benefit from arbuscular mycorrhiza to crop P nutrition and growth in 
617

618

619

620

621

622

623

624

625

626

627

628

629

630

631

632

633

634

635

636

637

638

639

640

641

642

643

644

contrasting cropping systems. Plant and Soil 350(1):85-98

Karasawa T, Takahashi S. 2015. Introduction of various cover crop species to improve soil biological P parameters and P uptake of the following crops. Nutrient Cycling in Agroecosystems 103(1):15-28

Karasawa T, Takebe M. 2012. Temporal or spatial arrangements of cover crops to promote arbuscular mycorrhizal colonization and $\mathrm{P}$ uptake of upland crops grown after nonmycorrhizal crops. Plant and Soil 353(1-2):355-366

Karasawa T, Kasahara Y, Takebe M. 2002. Differences in growth responses of maize to preceding cropping caused by fluctuation in the population of indigenous arbuscular mycorrhizal fungi. Soil Biology and Biochemistry 34(6):851-857

Kowalchuk GA, de Souza FA, van Veen JA. 2002 Community analysis of arbuscular mycorrhizal fungi associated with Ammophila arenaria in Dutch coastal sand dunes. Molecular Ecology 11(3):571-581

Liang ZB, Drijber RA, Lee DJ, Dwiekat IM, Harris SD, Wedin DA. 2008. A DGGE-cloning method to characterize arbuscular mycorrhizal community structure in soil. Soil Biology and Biochemistry 4:956-966

Lin X, Feng Y, Zhang H, Chen R, Wang J, Zhang J, Chu H. 2012. Long-term balanced fertilization decreases arbuscular mycorrhizal fungal diversity in an arable soil in north China revealed by 454 pyrosequencing. Environmental Science and Technology 46(11):5764-5771

Liu YJ, Shi GX, Mao L, Cheng G, Jiang SJ, Ma XJ, An LZ, Du GZ, Johnson NC, Feng H. 2012. Direct and indirect influences of $8 \mathrm{yr}$ of nitrogen and phosphorus fertilization on Glomeromycota in an alpine meadow ecosystem. New Phytologoist 194(2):523-535

Liu W, Zhang Y, Jiang S, Deng Y, Christie P, Murray PJ, Li X, Zhang J. 2016. Arbuscular mycorrhizal fungi in soil and roots respond differently to phosphorus inputs in an intensively managed calcareous agricultural soil. Scientific Reports 6:24902

Lynch JP. 2007. Roots of the second green revolution. Australian Journal of Botany 55(5):493512 
645

646

647

648

649

650

651

652

653

654

655

656

657

658

659

660

661

662

663

664

665

666

667

668

669

670

671

672

Maček I, Dumbrell AJ, Nelson M, Fitter AH, Vodnik D, Helgason T. 2011. Local adaptation to soil hypoxia determines the structure of an arbuscular mycorrhizal fungal community in roots from natural $\mathrm{CO}_{2}$ springs. Applied Environmental Microbiology 77(14):4770-4777

Maherali H, Klironomos JN. 2007. Influence of phylogeny on fungal community assembly and ecosystem functioning. Science 316(5832):1746-1748

Miranda JD, Harris PJ. 1994. Effects of soil phosphorus on spore germination and hyphal growth of arbuscular mycorrhizal fungi. New Phytologist 128(1):103-108

Mishima S, Itahashi S, Kimura R, Inoue, T. 2003. Trends of phosphate fertilizer demand and phosphate balance in farmland soils in Japan. Soil Science and Plant Nutrition 49(1):39-45

Murphy J, Riley P. 1962. A modified single solution method for the determination of phosphate in natural waters. Analytica Chimica Acta 27:31-36

Oksanen, J. 2017. Multivariate analysis of ecological communities in R: vegan tutorial. URL:http://cran.r-project.org

Powell JR, Parrent JL, Hart MM, Klironomos JN, Rillig M, Maherali H. 2009. Phylogenetic trait conservatism and the evolution of functional trade-offs in arbuscular mycorrhizal fungi. Proceedings of the Royal Society B: Biological Sciences 276:4237-4245

Ryan MH, Norton RM, Kirkegaard JA, McCormick KM, Knights SE, Angus JF. 2002. Increasing mycorrhizal colonization does not improve growth and nutrition of wheat on Vertosols in south-eastern Australia. Crop Pasture Science 53(10):1173-1181

Schneider KD, Lynch DH, Dunfield K, Khosla K, Jansa J, Voroney RP. 2015. Farm system management affects community structure of arbuscular mycorrhizal fungi. Applied Soil Ecology 96:192-200

Schüßler A, Gehrig H, Schwarzott D, Walker C. 2001a. Analysis of partial Glomales SSU rRNA gene sequences: implications for primer design and phylogeny. Mycological Research 105(1):5-15

Schüßler A, Schwarzott D, Walker C. 2001b. A new fungal phylum, the Glomeromycota: phylogeny and evolution. Mycological Research 105(12):1413-1421

Simon L, Lalonde M, Bruns TD. 1992. Specific amplification of 18 S fungal ribosomal genes 
673

674

675

676

677

678

679

680

681

682

683

684

685

686

687

688

689

690

691

692

693

694

695

696

697

698

699

700

from vesicular-arbuscular endomycorrhizal fungi colonizing roots. Applied and Environmental Microbiology 58(1):291-295

Smith SE, Read DJ. 2008. Arbuscular mycorrhizaes. In Smith SE, Read DJ (Eds), Mycorrhizal symbiosis 3rd Edition. Academic Press, London, pp.13-187

Smith SE, Smith FA, Jakobsen I. 2003. Mycorrhizal fungi can dominate phosphate supply to plants irrespective of growth responses. Plant Physiology 133(1):16-20

Sorensen JN, Larsen J and Jakobsen I. 2005. Mycorrhiza formation and nutrient concentration in leeks (Allium porrum) in relation to previous crop and cover crop management on high $\mathrm{P}$ soils. Plant and Soil 273(1-2):101-114

Thonar C, Erb A, Jansa, J. 2012. Real-time PCR to quantify composition of arbuscular mycorrhizal fungal communities-marker design, verification, calibration and field validation. Molecular Ecology Resources 12(2):219-232

Truog E. 1930. The determination of the readily available phosphorus of soils. Journal of The American Society of Agronomy 22:874-882

Turrini A, Sbrana C, Avio L, Njeru EM, Bocci G, Bàrberi P, and Giovannetti M. 2016. Changes in the composition of native root arbuscular mycorrhizal fungal communities during a shortterm cover crop-maize succession. Biology and Fertility of Soils 52(5):643-653

van der Heijden MGA, Klironomos JN, Ursic M, Moutoglis P, Streitwolf-Engel R, Boller T, Wiemken A, Sanders IR. 1998. Mycorrhizal fungal diversity determines plant biodiversity, ecosystem variability and productivity. Nature 396(5):72-75

Verbruggen E, van der Heijden MGA, Rillig MC, Kiers ET. 2013. Mycorrhizal fungal establishment in agricultural soils: factors determining inoculation success. New Phytologist 197(4):1104-1109

Verbruggen E, Kiers ET. 2010. Evolutionary ecology of mycorrhizal functional diversity in agricultural systems. Evolutionary Applications 3(5-6):547-560

Vierheilig H, Coughlan AP, Wyss U, Piché Y. 1998. Ink and vinegar, a simple staining technique for arbuscular-mycorrhizal fungi. Applied and Environmental Microbiology 64(12):5004-5007 
701 Wagg C, Jansa J, Schmid B, van der Heijden MGA. 2011. Belowground biodiversity effects of 702 plant symbionts support aboveground productivity. Ecological Letters 14(10):1001-1009 703 Wakelin S, Mander C, Gerard E, Jansa J, Erb A, Young S, Condron L, O’Callaghan M. 2012.

704 Response of soil microbial communities to contrasted histories of phosphorus fertilisation in 705 pastures. Applied Soil Ecology 61:40-48

706 Wang C, White PJ, Li CJ. 2017. Colonization and community structure of arbuscular 707 mycorrhizal fungi in maize roots at different depths in the soil profile respond differently to 708 phosphorus inputs on a long-term experimental site. Mycorrhiza 27(4):369-381

709

710

711

712

713

714

715

716

717
Xiang X, Gibbons SM, He J, Wang C, He D, Li Q, Ni Y, Chu H. 2016. Rapid response of arbuscular mycorrhizal fungal communities to short-term fertilization in an alpine grassland on the Qinghai-Tibet Plateau. PeerJ 4:e2226

Zhang F, Hamel C, Kianmehr H, Smith DL. 1995. Root-zone temperature and soybean [Glycine $\max ($ L.) Merr.] vesicular-arbuscular mycorrhizae: development and interactions with the nitrogen fixing symbiosis. Environmental Experimental Botany 35(3):287-298

Zhao H, Li X, Zhang Z, Zhao Y, Yang J, Zhu Y. 2017. Species diversity and drivers of arbuscular mycorrhizal fungal communities in a semi-arid mountain in China. PeerJ 5:e4155 


\section{Figure 1 (on next page)}

Summary of the experimental design of this cover crop rotational study. 
Phase 1
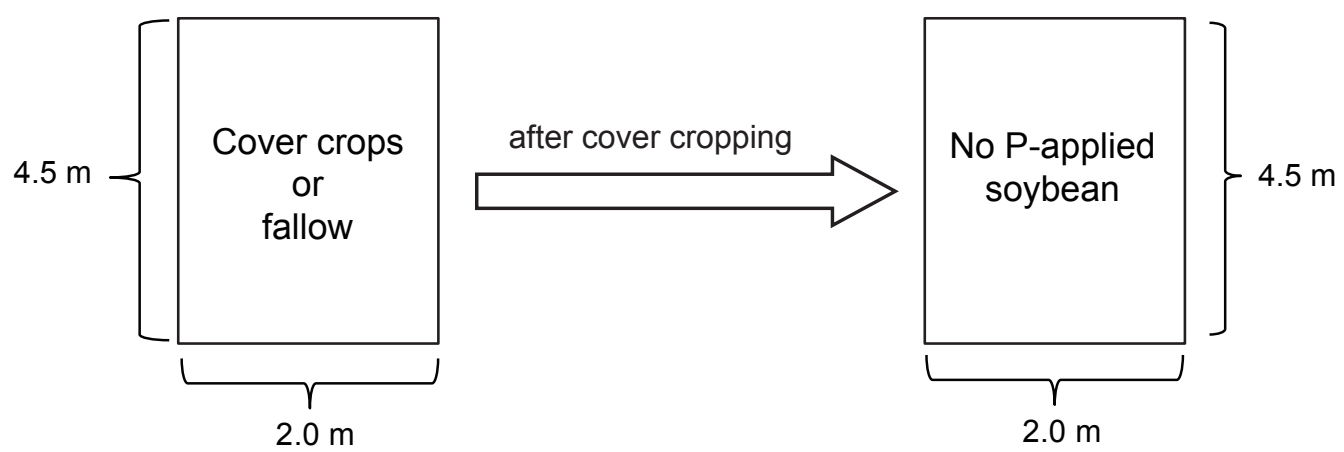

The plot was divided into two

Phase 2

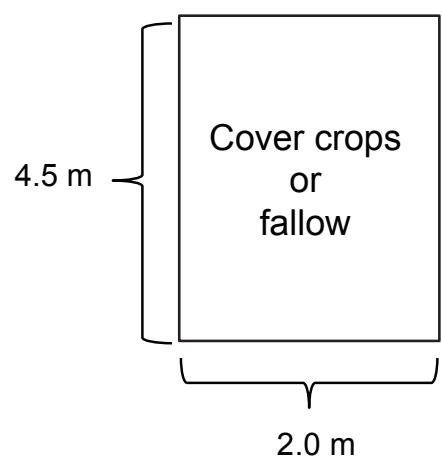
subplots prior to soybean

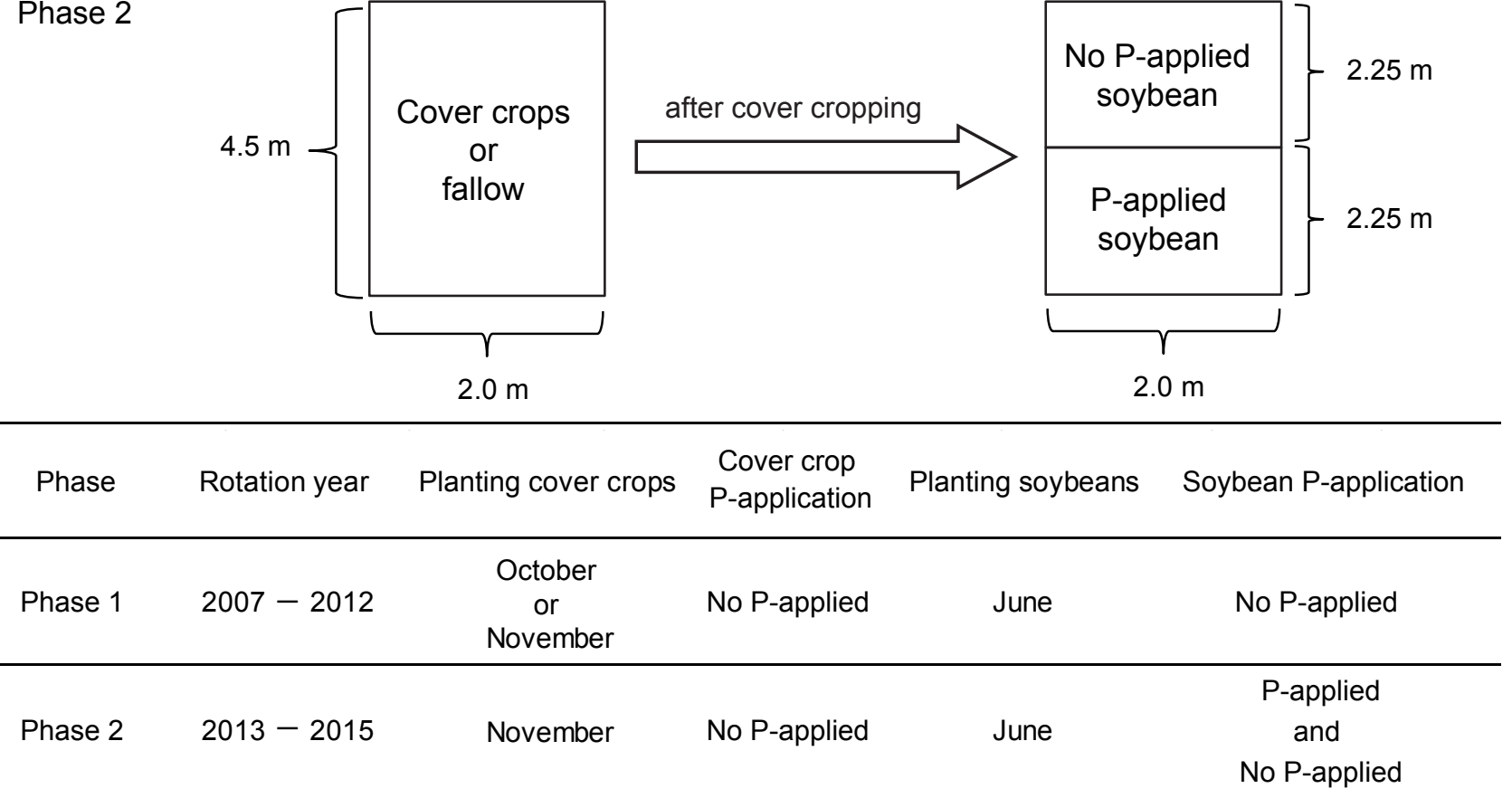




\section{Figure 2 (on next page)}

Impact of cover cropping and phosphorus $(\mathrm{P})$ regime on the available soil $\mathrm{P}$ and root colonization of arbuscular mycorrhizal fungi (AMF) in the soybean at full bloom stage (R2) in 2014 and 2015.

Different letters within the same column for each variable in no P- or P-application plot among the cover crop systems show a significant difference by Tukey's test at the $5 \%$ level. n.s. $=$ not significant, $*$ and $* *$ indicates a significant difference at $5 \%$ and $1 \%$ level by t-test. Error bars indicate standard errors of the mean $(n=3)$. 


\section{Manuscript to be reviewed}
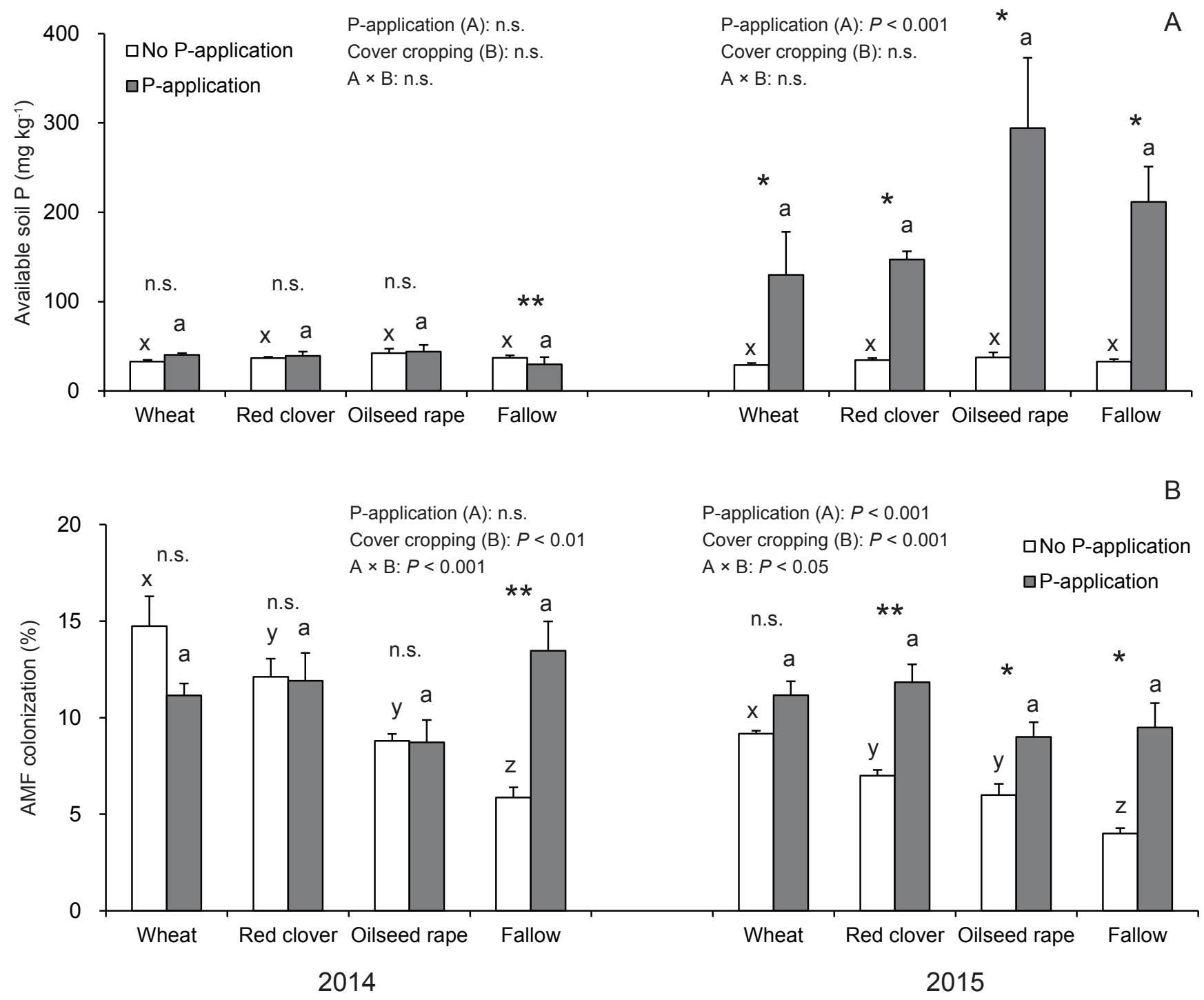
Figure 3 (on next page)

Impact of cover cropping and phosphorus $(\mathrm{P})$ regime on the growth performance of the soybean at full bloom stage (R2) and maturity stage (R8) in 2014 and 2015.

Different letters within the same column for each variable in no P- or P-application plot among the cover crop systems show a significant difference by Tukey's test at the $5 \%$ level. n.s. $=$ not significant, $*$ and $* *$ indicates a significant difference at $5 \%$ and $1 \%$ level by t-test. Error bars indicate standard errors of the mean $(n=3)$. 

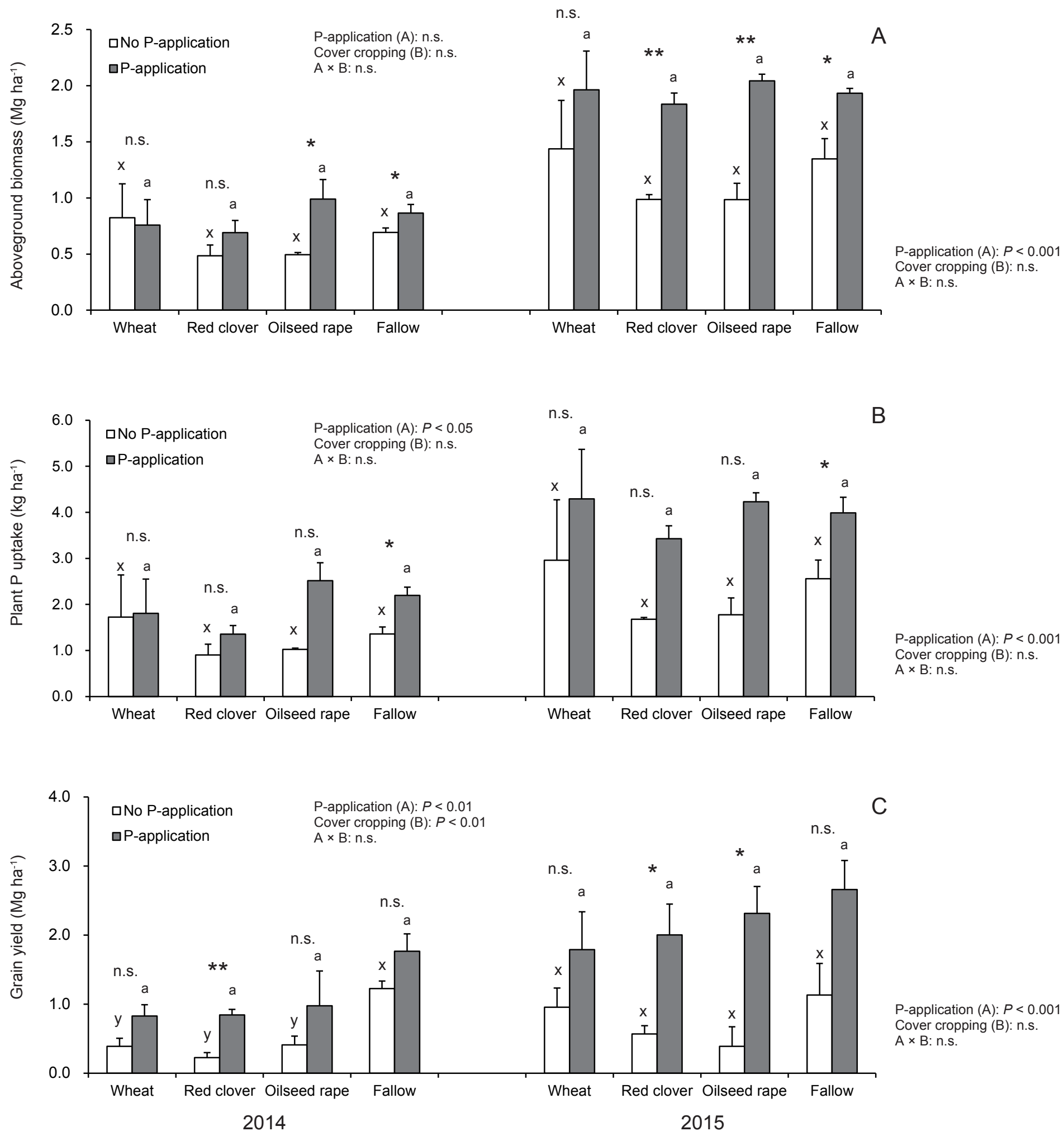
Figure 4 (on next page)

Impact of cover cropping and phosphorus $(\mathrm{P})$ regime on the diversity of AMF communities colonizing the soybean roots at full bloom stage (R2) in 2014 and 2015.

Different letters within the same column for each variable in no P- or P-application plot among the cover crop systems show a significant difference by Tukey's test at the $5 \%$ level. n.s. $=$ not significant, $*$ and $* *$ indicates a significant difference at $5 \%$ and $1 \%$ level by t-test. Error bars indicate standard errors of the mean $(n=3)$. 


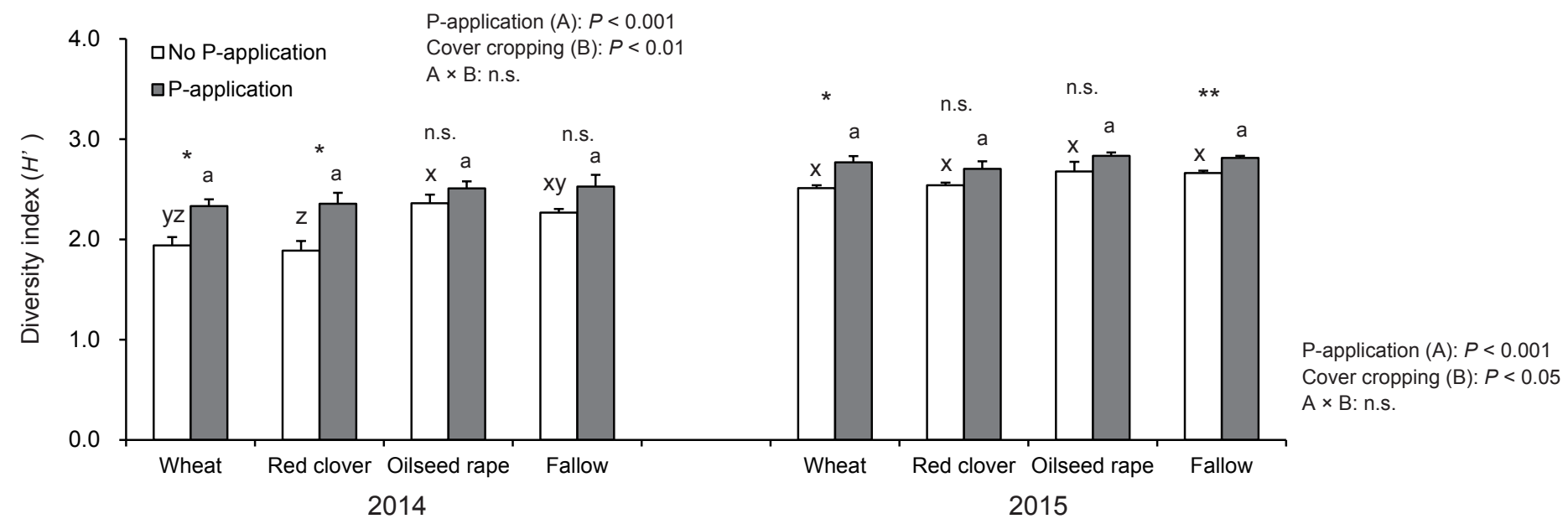




\section{Figure 5 (on next page)}

Redundancy analysis (RDA) biplot showing the relationship among the AMF communities, cover cropping and phosphorus (P) application in 2014 and 2015.

The eigenvalues of the first and second axes were 3.680 and 2.253 , respectively. Solid lines indicate significant effects, and dashed lines indicate non-significant effects. The environmental variable of cover cropping and P-application was coded as a dummy variable (0 and 1). The no-P and P-application are distinguished by clear shapes for no-P application and filled shapes for P-application plots. Wheat $=$ circle, red clover $=$ square, oilseed rape $=$ triangle, fallow = diamond. 


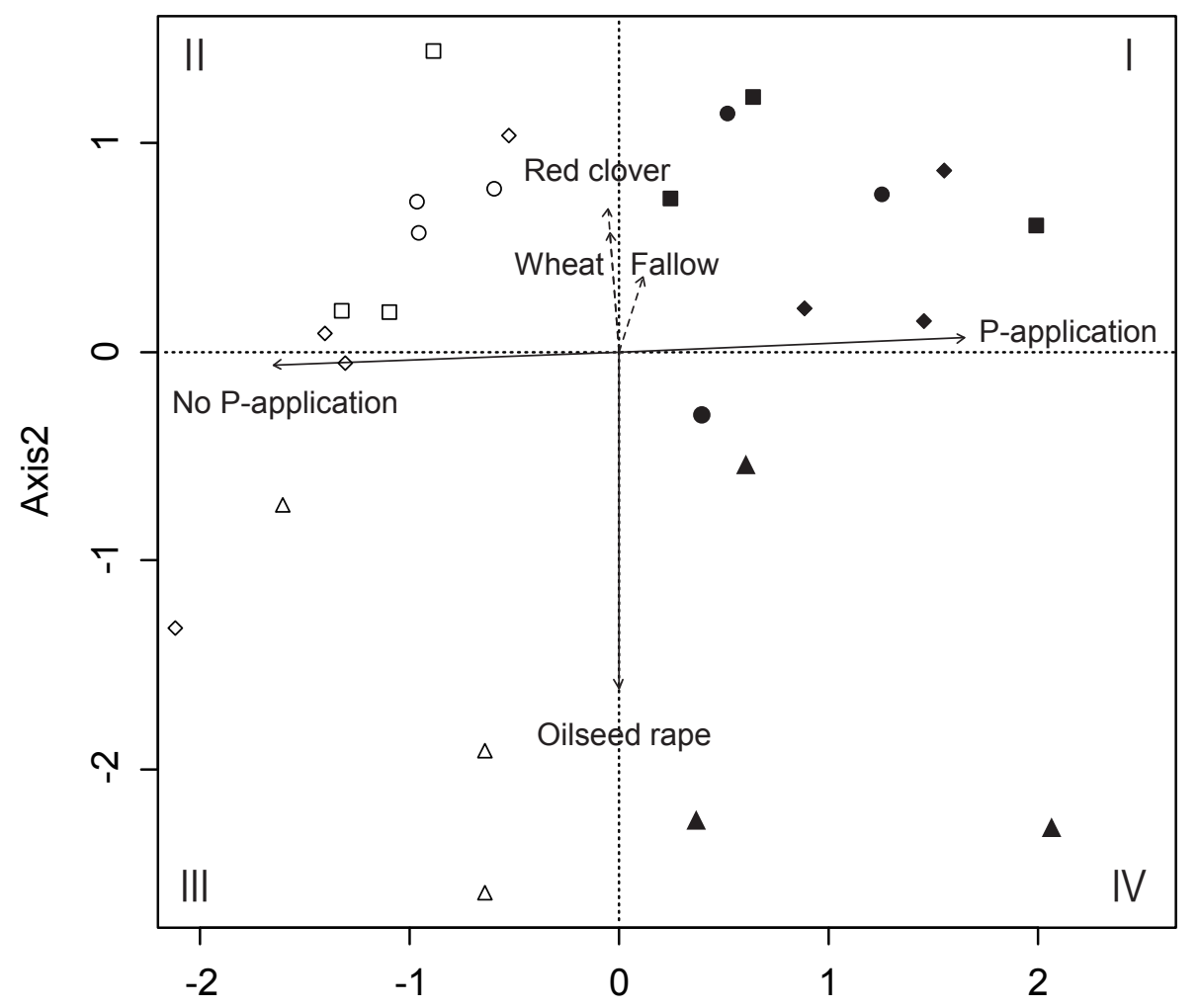

A: 2014

o P-Wheat

$\square$ P- Red clover

$\triangle \mathrm{P}$ - Oilseed rape

$\diamond \mathrm{P}$ - Fallow

- P+ Wheat

- P+ Red clover

- $P+$ Oilseed rape

- P+ Fallow

P-application: $F=4.263, P=0.001$

Cover crop: $F=1.193, P=0.189$

Axis1

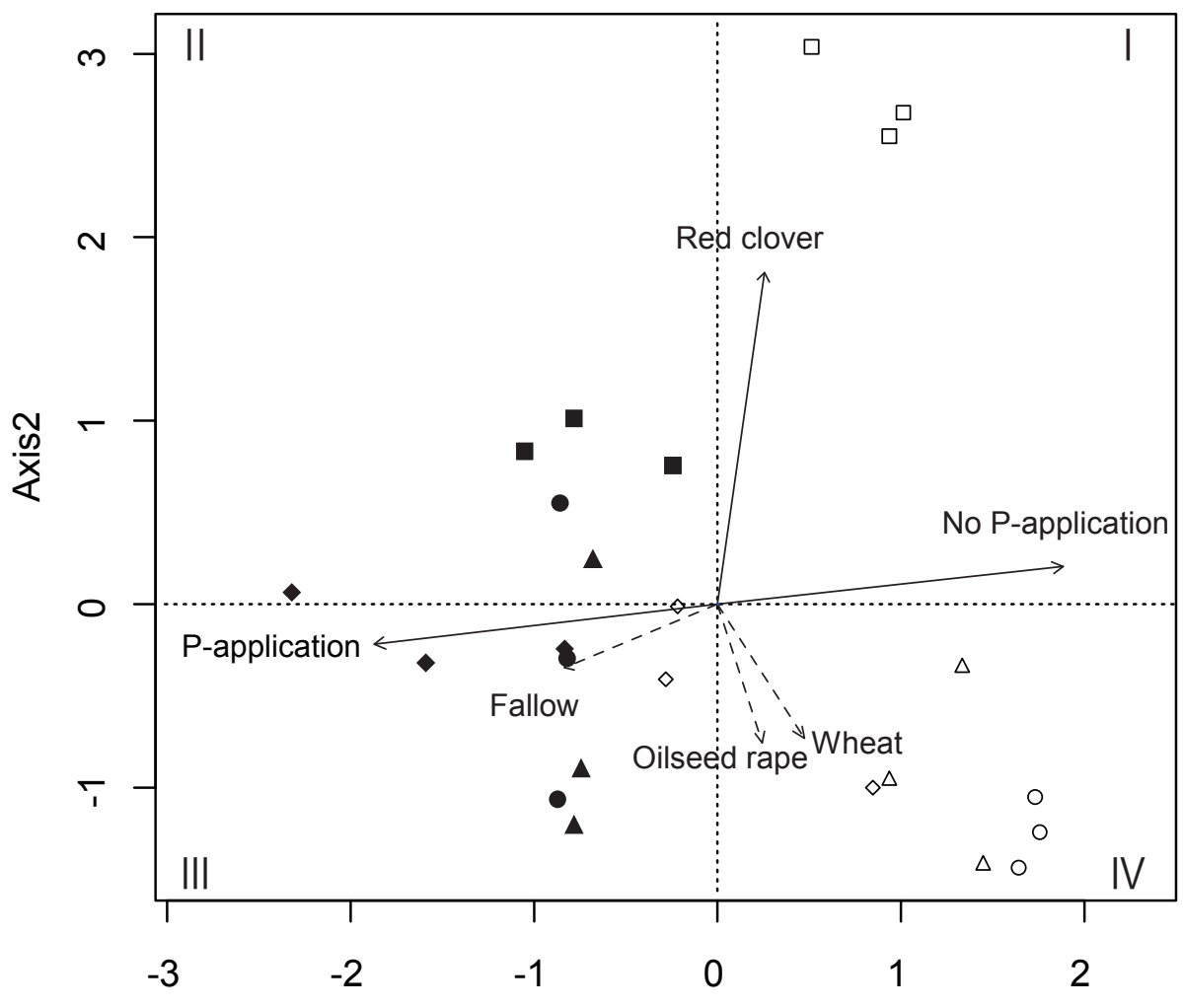

B: 2015

o P-Wheat

$\square$ P- Red clover

$\triangle \mathrm{P}$ - Oilseed rape

$\diamond \mathrm{P}$ - Fallow

- P+ Wheat

- P+ Red clover

- $\mathrm{P}+$ Oilseed rape

- P+ Fallow

P-application: $F=4.226, P=0.001$

Cover cropping: $F=1.669, P=0.057$

Axis1 
Figure $\mathbf{6}$ (on next page)

Soybean growth and arbuscular mycorrhizal fungal (AMF) response for phosphorus (P) nutrition, growth and grain yield with or without $\mathrm{P}$-application in this study.

The observations with and without P-application are denoted by open square and open circles, respectively. The number above each line represents the value of the Pearson's correlation coefficient. Solid lines indicate P-application plots, and dashed lines indicate no Papplication plots. The data of both years in 2014 and 2015 are included. 
PeerJ
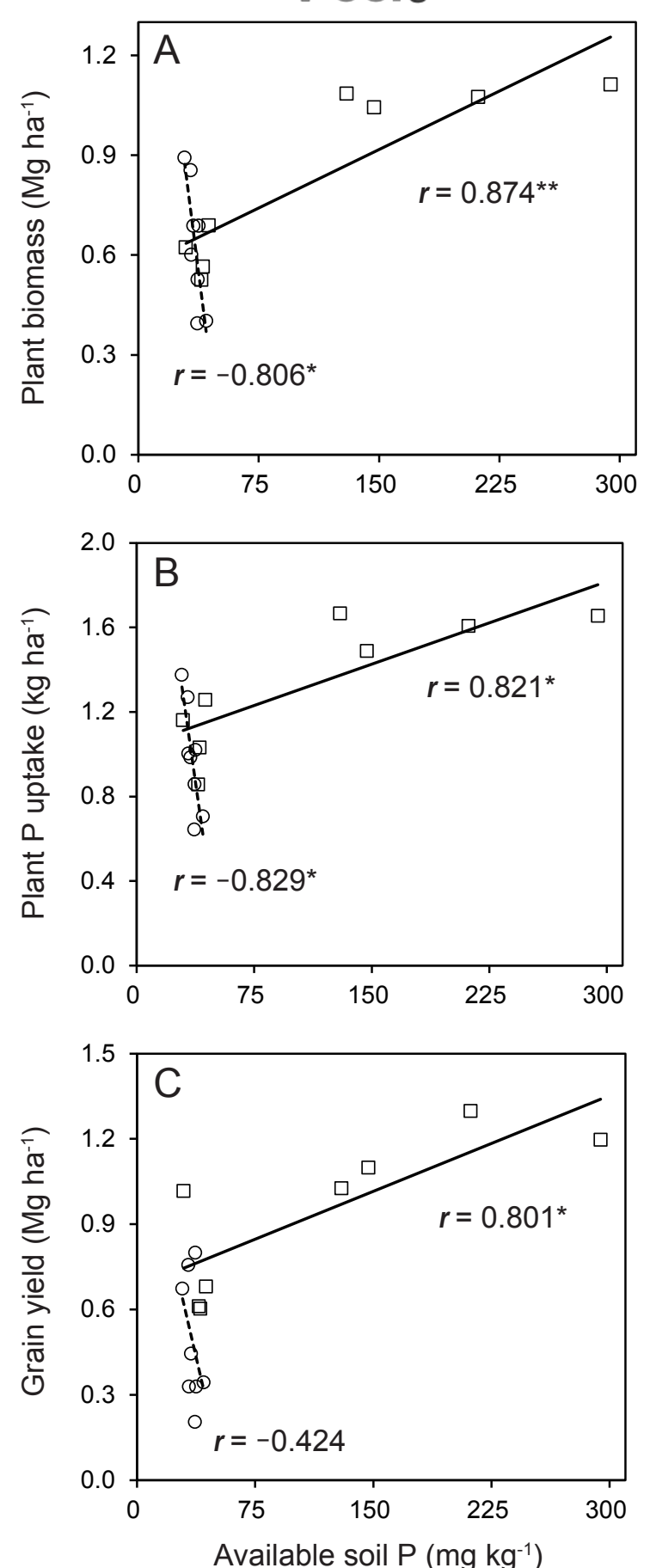

Manuscript to be reviewed
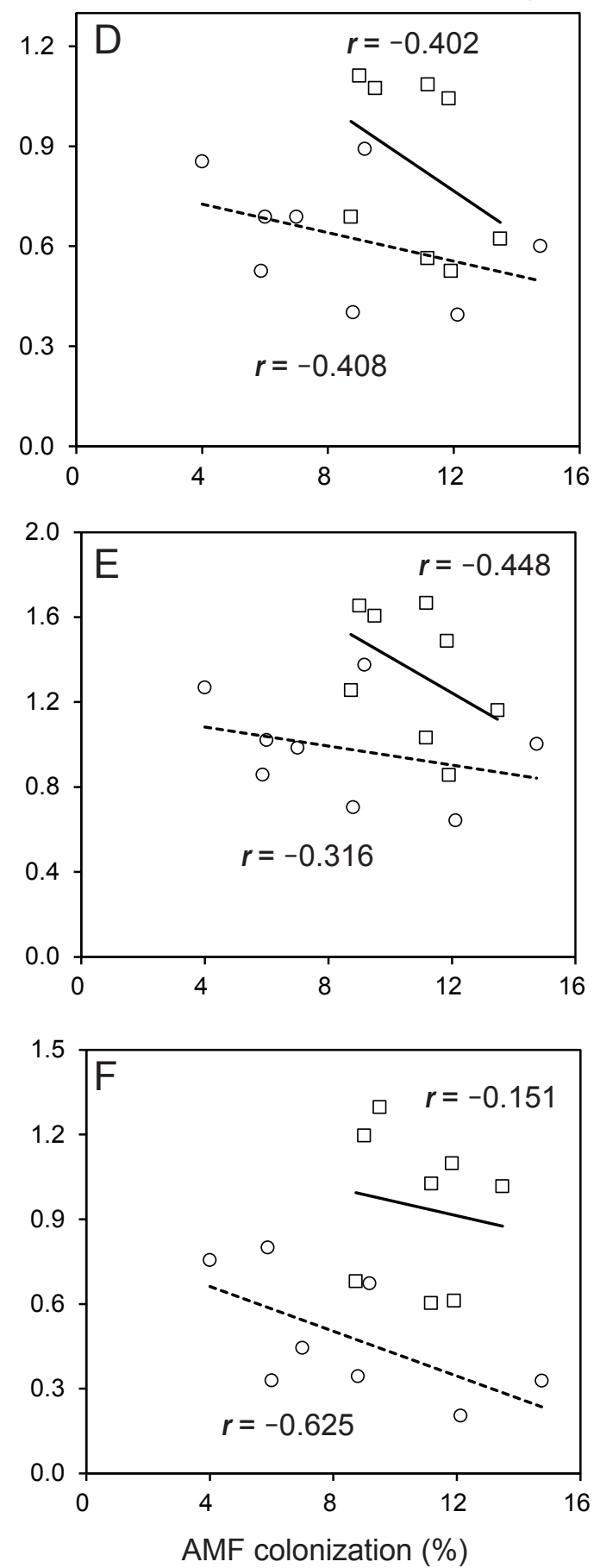
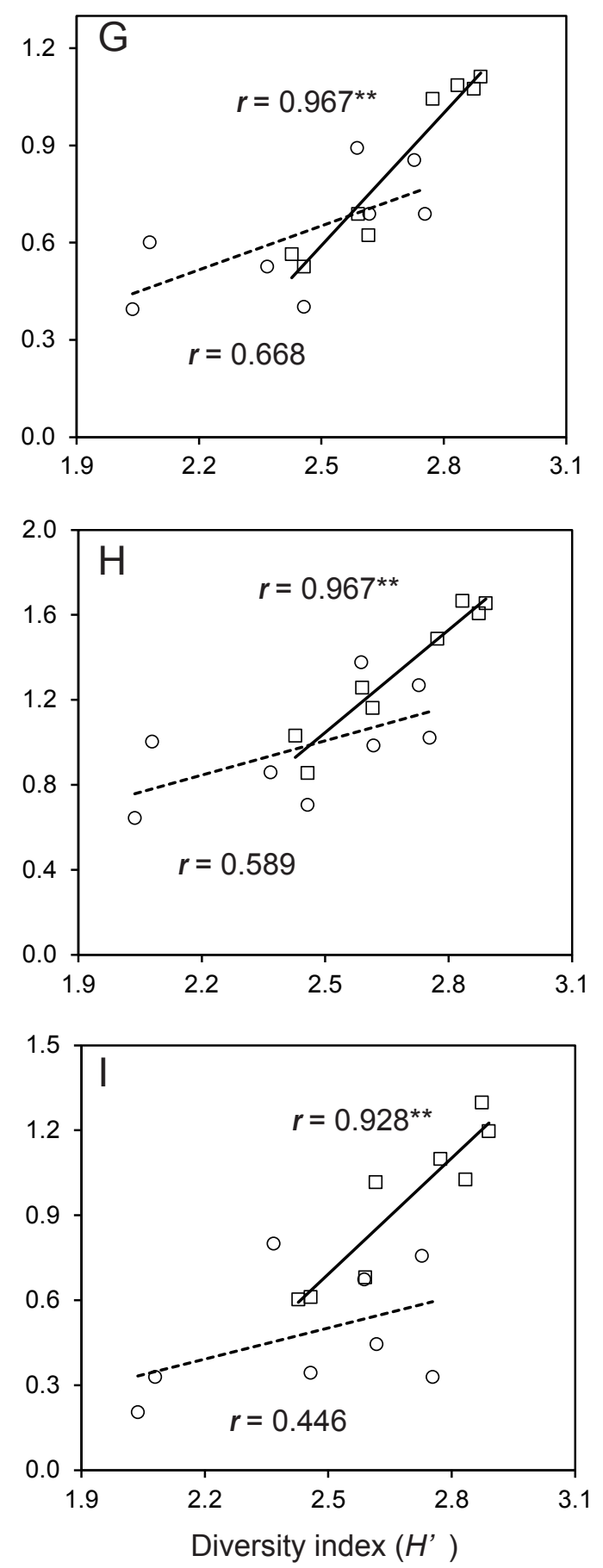
Figure 7 (on next page)

Network analysis showing relatedness between soybean performance and arbuscular mycorrhizal fungal (AMF) parameters in the two-year field trial.

Each circle represents a variable in the model, while the number above each arrow represents the value of the Pearson's correlation coefficient. Solid lines indicate positive relationships, and dashed lines indicate negative relationships. The data of both years in 2014 and 2015 are included. $*$ and ${ }^{* *}$ show a significant difference $(P<0.05$ and $P<0.01$, respectively). 


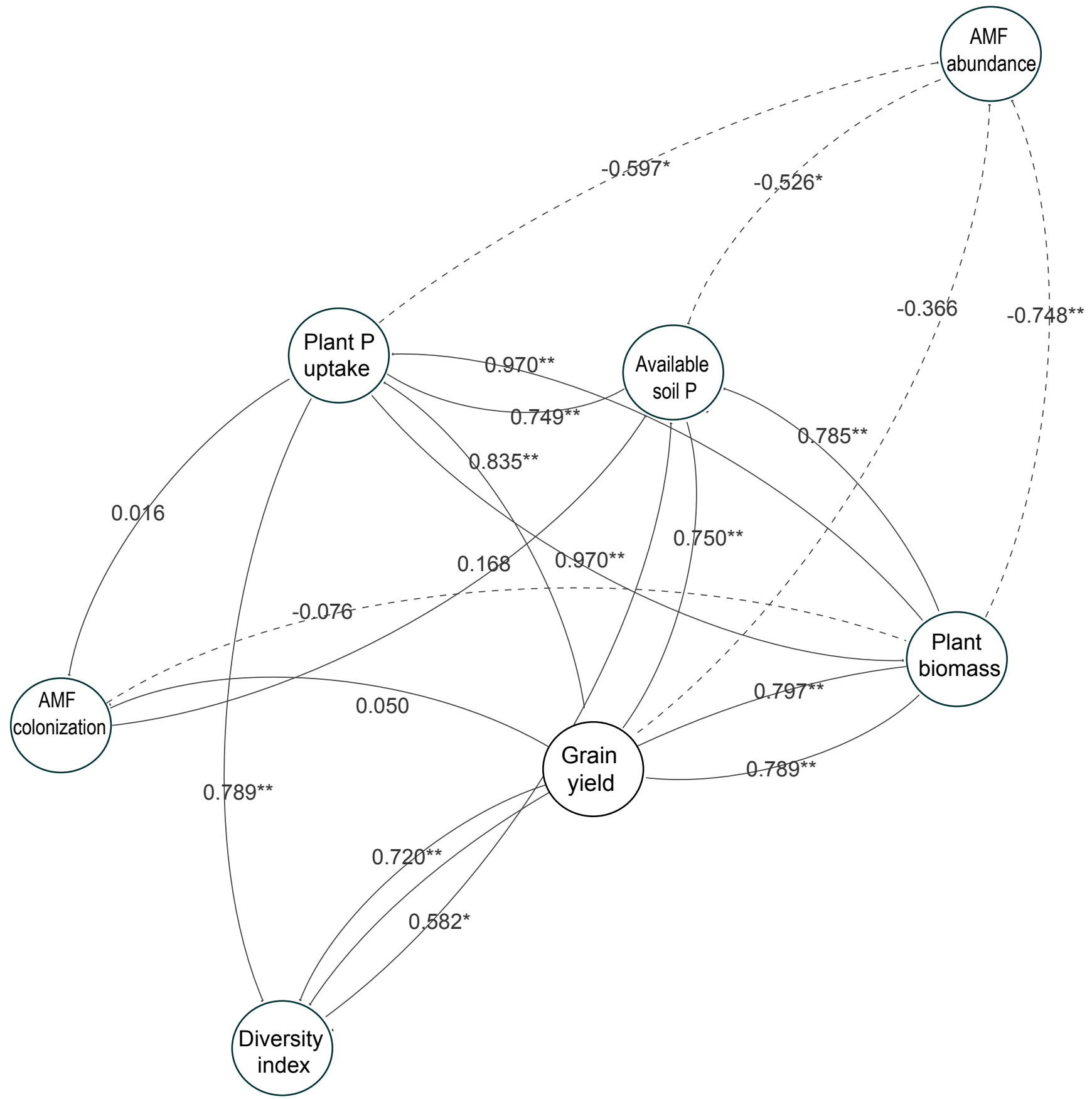




\section{Table $\mathbf{1}$ (on next page)}

Impact of cover cropping and phosphorus $(\mathrm{P})$ regime on the abundance of different arbuscular mycorrhizal fungal (AMF) taxa colonizing soybean roots at full bloom stage (R2) in 2014 and 2015.

Different letters within the same column for each variable in no P- or P-application plot among the cover crop systems show a significant difference by Tukey's test at the $5 \%$ level. n.s. $=$ not significant, $*$ and $* *$ indicates a significant difference at $5 \%$ and $1 \%$ level by t-test. Numbers denote means of $\mathrm{n}=3$ and standard error in parentheses. 


\begin{tabular}{|c|c|c|c|c|c|c|c|c|c|c|c|}
\hline \multirow[t]{2}{*}{ Rotation year } & \multirow[t]{2}{*}{ P-application } & \multirow[t]{2}{*}{ Cover crop } & \multicolumn{3}{|c|}{$\begin{array}{l}\text { R.irregularis } \\
\text { (Log gene copies } \mathrm{mg}^{-1} \mathrm{dry} \text { root) }\end{array}$} & \multicolumn{3}{|c|}{$\begin{array}{l}\text { F.mosseae } \\
\text { (Log gene copies } \mathrm{mg}^{-1} \mathrm{dry} \text { root) }\end{array}$} & \multicolumn{3}{|c|}{$\begin{array}{l}\text { C.claroideum } \\
\text { (Log gene copies } \mathrm{mg}^{-1} \mathrm{dry} \text { root) }\end{array}$} \\
\hline & & & No P-application & P-application & & No P-application & P-application & & No P-application & & \\
\hline \multirow[t]{7}{*}{2014} & $52.5 \mathrm{~kg} \mathrm{ha}^{-1}$ & Wheat & $15.4(0.89) \mathrm{a}$ & $18.0(0.28) \mathrm{a}$ & n.s. & $9.8(0.63) a$ & $10.8(0.28) a$ & n.s. & $17.0(0.44) a$ & $17.5(0.16) \mathrm{a}$ & n.s. \\
\hline & & Red clover & $16.5(0.10) \mathrm{a}$ & $18.0(0.58) \mathrm{a}$ & n.s. & $9.2(0.26) a$ & $11.6(0.65) \mathrm{a}$ & * & $16.3(0.36) \mathrm{a}$ & $18.6(0.50) a$ & * \\
\hline & & Oilseed rape & $16.9(0.74) a$ & $19.0(0.05) \mathrm{a}$ & * & $8.5(0.48) a$ & $11.9(0.37) \mathrm{a}$ & ** & $15.4(0.37) \mathrm{a}$ & $19.0(0.63) \mathrm{a}$ & ** \\
\hline & & Fallow & $15.6(0.44) \mathrm{a}$ & $17.6(0.20) \mathrm{a}$ & * & $9.2(0.61) \mathrm{a}$ & $10.7(0.17) \mathrm{a}$ & n.s. & $16.1(0.65) \mathrm{a}$ & $17.8(0.22) \mathrm{a}$ & n.s. \\
\hline & & Analysis of variance & & & & & & & & & \\
\hline & & P-application (A) & $P<0.001$ & & & $P<0.001$ & & & $P<0.001$ & & \\
\hline & & $\begin{array}{l}\text { Cover cropping (B) } \\
A \times B\end{array}$ & $\begin{array}{l}\text { n.s. } \\
\text { n.s. }\end{array}$ & & & $\begin{array}{l}\text { n.s. } \\
\text { n.s. }\end{array}$ & & & $\begin{array}{l}\text { n.s. } \\
P<0.05\end{array}$ & & \\
\hline \multirow[t]{7}{*}{2015} & $157.5 \mathrm{~kg} \mathrm{ha}^{-1}$ & Wheat & $10.4(0.32) \mathrm{a}$ & $9.3(0.21) a$ & * & $9.6(0.33) a$ & $9.7(0.06) \mathrm{a}$ & n.s. & $13.1(0.41) \mathrm{a}$ & $13.7(0.00) \mathrm{a}$ & n.s. \\
\hline & & Red clover & $10.7(0.27) a$ & $9.5(0.30)$ a & * & $10.0(0.29) \mathrm{a}$ & $10.3(0.07) \mathrm{a}$ & n.s. & $13.7(0.32) a$ & $13.9(0.23)$ a & n.s. \\
\hline & & Oilseed rape & $10.6(0.12) \mathrm{a}$ & $9.5(0.26) \mathrm{a}$ & * & $10.1(0.12) \mathrm{a}$ & $10.2(0.10) \mathrm{a}$ & n.s. & $13.7(0.15) \mathrm{a}$ & $14.0(0.20) \mathrm{a}$ & n.s. \\
\hline & & $\begin{array}{l}\text { Fallow } \\
\text { Analvsis of variance }\end{array}$ & $10.1(0.24) \mathrm{a}$ & $9.6(0.28) a$ & n.s. & $9.7(0.17) a$ & $10.2(0.37) \mathrm{a}$ & n.s. & $13.3(0.14) \mathrm{a}$ & $14.1(0.66) \mathrm{a}$ & n.s. \\
\hline & & P-application (A) & $P<0.001$ & & & n.s. & & & n.s. & & \\
\hline & & Cover cropping (B) & n.s. & & & n.s. & & & n.s. & & \\
\hline & & $A \times B$ & n.s. & & & n.s. & & & n.s. & & \\
\hline \multirow[t]{2}{*}{ Rotation year } & P-application & Cover crop & \multicolumn{3}{|c|}{$\begin{array}{l}\text { G.margarita } \\
\text { (Log gene copies } \mathrm{mg}^{-1} \mathrm{dry} \text { root) }\end{array}$} & \multicolumn{3}{|c|}{$\begin{array}{l}\text { Ce.pellucida } \\
\text { (Log gene copies } \mathrm{mg}^{-1} \mathrm{dry}_{\text {root})}\end{array}$} & \multicolumn{3}{|c|}{$\begin{array}{l}\text { D.celata } \\
\text { (Log gene copies } \mathrm{mg}^{-1} \mathrm{dry} \text { root) }\end{array}$} \\
\hline & & & No P-application & P-application & & No P-application & P-application & & No P-application & P-application & \\
\hline \multirow[t]{8}{*}{2014} & $52.5 \mathrm{~kg} \mathrm{ha}^{-1}$ & Wheat & $14.0(0.77) \mathrm{a}$ & $15.6(0.31) \mathrm{a}$ & n.s. & $13.9(0.55) \mathrm{a}$ & $14.9(0.23) \mathrm{a}$ & n.s. & $16.1(0.70) \mathrm{a}$ & $17.2(0.17) \mathrm{a}$ & n.s. \\
\hline & & Red clover & $13.6(0.38)$ a & $14.8(0.18) a$ & * & $13.4(0.11) \mathrm{a}$ & $16.1(0.51) \mathrm{a}$ & ** & $15.6(0.15) \mathrm{a}$ & $18.5(0.53)$ a & ** \\
\hline & & Oilseed rape & $13.0(0.86) \mathrm{a}$ & $15.1(0.35) \mathrm{a}$ & n.s. & $12.6(0.63) \mathrm{a}$ & $15.9(0.16) \mathrm{a}$ & ** & $15.2(0.59) \mathrm{a}$ & $17.7(0.25) \mathrm{a}$ & * \\
\hline & & Fallow & $13.3(0.64) \mathrm{a}$ & $15.5(0.35) \mathrm{a}$ & * & $13.1(0.35) \mathrm{a}$ & $14.9(0.14) \mathrm{a}$ & ** & $15.6(0.49)$ a & $17.4(0.17) \mathrm{a}$ & * \\
\hline & & Analysis of variance & & & & & & & & & \\
\hline & & P-application (A) & $P<0.001$ & & & $P<0.001$ & & & $P<0.001$ & & \\
\hline & & Cover cropping (B) & n.s. & & & n.s. & & & n.s. & & \\
\hline & & $\mathrm{A} \times \mathrm{B}$ & n.s. & & & $P<0.05$ & & & n.s. & & \\
\hline \multirow[t]{7}{*}{2015} & $157.5 \mathrm{~kg} \mathrm{ha}^{-1}$ & Wheat & $6.4(0.51) a$ & $6.4(0.36) a$ & n.s. & $14.1(0.43) a$ & $13.7(0.12) \mathrm{a}$ & n.s. & $14.4(0.46) \mathrm{a}$ & $13.9(0.26) a$ & n.s. \\
\hline & & Red clover & $6.9(0.56)$ a & $7.0(0.21) a$ & n.s. & $14.5(0.22) \mathrm{a}$ & $13.9(0.40) a$ & n.s. & $14.6(0.35) \mathrm{a}$ & $14.1(0.48) \mathrm{a}$ & n.s. \\
\hline & & Oilseed rape & $6.4(0.43) a$ & $6.5(0.54) a$ & n.s. & $14.9(0.21) a$ & $13.6(0.19) \mathrm{a}$ & * & $14.6(0.15) \mathrm{a}$ & $14.5(0.29) \mathrm{a}$ & n.s. \\
\hline & & $\begin{array}{l}\text { Fallow } \\
\text { Analysis of variance }\end{array}$ & $5.9(0.21) a$ & $6.3(0.51)$ a & n.s. & $14.2(0.08) \mathrm{a}$ & $13.9(0.24) \mathrm{a}$ & n.s. & $14.7(0.54) \mathrm{a}$ & $14.1(0.35) \mathrm{a}$ & n.s. \\
\hline & & P-application (A) & n.s. & & & $P<0.01$ & & & n.s. & & \\
\hline & & Cover cropping (B) & n.s. & & & n.s. & & & n.s. & & \\
\hline & & $A \times B$ & n.s. & & & n.s. & & & n.s. & & \\
\hline
\end{tabular}

